\title{
Metasomatism-induced mantle magnesium isotopic heterogeneity: Evidence from pyroxenites
}

\author{
Yan $\mathrm{Hu}^{1,2^{*}}$, Fang-Zhen Teng ${ }^{1}$, Hong-Fu Zhang ${ }^{2}$, Yan $\mathrm{Xiao}^{2}$, Ben-Xun $\mathrm{Su}^{2}$
}

1. Isotope Laboratory, Department of Earth and Space Sciences, University of Washington, Seattle, WA 98195-1310, USA

2. State Key Laboratory of Lithospheric Evolution, Institute of Geology and Geophysics, Chinese Academy of Sciences, P.O. Box 9825, Beijing 100029, China

\author{
Abstract: 309 words \\ Text: 7683 words \\ Table: 6 \\ Figures: 11 \\ Submitted to Geochimica et Cosmochimica Acta \\ Special issue: Magmas and their sources: A tribute to Fred Frey
}

(October, 2015)

*Corresponding author:

Email: yanhu@uw.edu 


\section{Abstract}

High-precision $\mathrm{Mg}$ isotopic measurements on diverse mantle pyroxenite xenoliths

3 collected from Hannuoba, North China Craton, revealed multi-stage interaction between

4 the lithospheric mantle with melts of different origins. The garnet-bearing pyroxenites

5 yield variable $\delta^{26} \mathrm{Mg}$ values from -0.48 to $-0.10 \%$, consistent with their origin as reaction

6 products between mantle peridotites and melts from subducted oceanic slab with highly

7 heterogeneous $\delta^{26} \mathrm{Mg}$. Most of their constituent olivine, clinopyroxene, and

8 orthopyroxene have indistinguishable $\delta^{26} \mathrm{Mg}$ ratios around the normal mantle range (-0.25

$9 \pm 0.07 \%$, Teng et al., 2010). The lack of fractionation among these three phases agrees

10 with their similar bonding environments for $\mathrm{Mg}$ (6-fold), and hence indicates a general

11 isotopic equilibrium among them. By contrast, garnets have variably lighter $\delta^{26} \mathrm{Mg}$ values

12 (-0.75 to $-0.37 \%, \mathrm{n}=15)$, consistent with their higher coordination number for $\mathrm{Mg}(8$ -

13 fold), and thus weaker Mg-O bonds. The magnitude of fractionation between garnet and

14 olivine/pyroxene, however, is not correlated with equilibrium temperature, and therefore

15 reflects disequilibrium $\mathrm{Mg}$ partitioning. Considering the metasomatic origin of these

16 garnets, the disequilibrium isotopic fractionation is most likely the result of rapid and

17 incomplete metasomatic reaction during which garnets were formed at the expense of

18 isotopically heavier co-existing minerals, particularly spinels. The two garnet-free

19 clinopyroxenites, which display highly enriched light rare earth element (LREE) patterns

20 and very low $\mathrm{Ti} / \mathrm{Eu}$ ratios, are characterized by extremely light $\delta^{26} \mathrm{Mg}$ (as low as $-1.51 \%$ ).

21 Their formation possibly indicates an episode of carbonatite infiltration. In comparison,

22 the $\mathrm{Cr}$ and $\mathrm{Al}$ websterites, as well as an orthopyroxenite, all have mantle-like whole-rock

23 and mineral $\delta^{26} \mathrm{Mg}$ ratios, with equilibrated clinopyroxene-orthopyroxene pairs. Their

24 presence thus implies different episodes of asthenosphere-derived silicate melt injection

25 into the mantle. Collectively, these observations suggest that mantle metasomatism plays

26 an important role in producing inter-mineral $\mathrm{Mg}$ isotopic disequilibrium and local $\mathrm{Mg}$

27 isotopic variation in the lithospheric mantle. Therefore, $\mathrm{Mg}$ isotopes can be used to trace

28 metasomatic activities in the mantle.

30 Keywords: Magnesium isotopes, pyroxenite xenoliths, mantle metasomatism,

31 disequilibrium fractionation, equilibrium fractionation 


\section{Introduction}

Magnesium is a major rock-forming element with three stable isotopes (mass 24,

34 25, and 26). The fractionation of $\mathrm{Mg}$ isotopes during partial melting and magma

35 differentiation is limited in the mantle ( $\leq 0.07 \%$ for $\delta^{26} \mathrm{Mg}$, Teng et al., 2007, 2010). By

36 contrast, over $7 \%$ fractionation in ${ }^{26} \mathrm{Mg} /{ }^{24} \mathrm{Mg}$ has been found at Earth's surface through

37 continental weathering and carbonate precipitation (Wombacher et al., 2011; Liu et al.,

38 2014). The highly variable $\delta^{26} \mathrm{Mg}$ values found in crustal materials compared with the

39 uniform $\delta^{26} \mathrm{Mg}$ ratios characterizing mantle-related rocks and minerals thus highlights the

40 potential of using Mg isotopes to trace crustal recycling (e.g., Yang et al., 2012).

A well-constrained mantle $\delta^{26} \mathrm{Mg}$ value is a prerequisite for resolving crustal

42 signal unambiguously from that of the mantle. Previous analyses on lherzolite-

43 harzburgite-dunite series peridotites worldwide yielded largely consistent $\delta^{26} \mathrm{Mg}$ values,

44 and hence suggest a homogeneous mantle $\left(\delta^{26} \mathrm{Mg}=-0.25 \pm 0.07 \%\right.$, Handler et al., 2009;

45 Yang et al., 2009; Bourdon et al., 2010; Teng et al., 2010; Huang et al., 2011; Liu et al.,

46 2011). However, more recent studies on strongly metasomatized peridotites, particularly

47 wehrlites, found $\delta^{26} \mathrm{Mg}$ values deviated from the mantle range (Yang et al., 2009; Pogge

48 von Strandmann et al., 2011; Xiao et al., 2013) with evidence for disequilibrium inter-

49 mineral fractionation (Young et al., 2009; Xiao et al., 2013). Meanwhile, continental

50 basalts are also frequently found to be distinctively depleted in heavy Mg isotopes (Yang

51 et al., 2012; Huang et al., 2015) when compared to the homogeneous oceanic basalts with

52 mantle-like $\delta^{26} \mathrm{Mg}$ (Bourdon et al., 2010; Teng et al., 2010). With the general recognition

53 of a compositionally heterogeneous mantle where magmatic refertilization is widespread

54 (Kelemen et al., 1998), it thus needs further investigation on the scale, distribution, and

55 extent of $\mathrm{Mg}$ isotopic heterogeneity caused by open-system isotopic exchanges between

56 mantle rocks and migrating metasomatic melts.

Pyroxenites that form veins cross-cutting the mantle are more direct samples than

58 metasomatized peridotites for this purpose as their occurrence marks zones of higher

59 melt/rock ratios in the mantle (Garrido and Bodinier, 1999). They have been variously

60 interpreted as high-pressure cumulates from migrating asthenosphere-derived magmas

61 (Frey, 1980; Irving, 1980), reaction products of metasomatic melts with mantle peridotite 
642007 for a review). Due to their more fusible nature than the ambient peridotites 65 (Anderson, 2005), pyroxenites have been regarded as an important lithologic 66 heterogeneity in the mantle, and are often invoked to explain the chemical and isotopic 67 variations observed in oceanic and continental basalts (Sobolev et al., 2005, 2007). Yet, 68 whether their presence will also cause $\mathrm{Mg}$ isotopic heterogeneity in the mantle and 69 related volcanic rocks is still unknown, due to the lack of Mg isotopic data on mantle 70 pyroxenites.

71 Here, we present the first systematic Mg isotopic analyses on a variety of mantle 72 pyroxenite xenoliths, along with major and trace element data for the whole rocks and 73 constituent minerals. The xenoliths were collected from the Hannuoba basaltic plateau 74 (27 to $14 \mathrm{Ma}$, Zhu, 1998) distributed along the north margin of the North China Craton 75 (NCC), where the entire section of the ancient lithospheric mantle has been modified by 76 intense and multi-stage melt-rock interactions (Tang et al., 2008). These xenoliths were 77 taken as physical evidence for different episodes of melt injection events (Chen et al., 78 2001; Xu, 2002; Fan et al., 2005; Liu et al., 2005, 2010c). Therefore, they are ideal 79 samples for studying the influence of mantle metasomatism on generating $\mathrm{Mg}$ isotopic 80 variation in the mantle. The variable $\mathrm{Mg}$ isotopic composition of the pyroxenites and 81 their disequilibrium inter-mineral fractionations indicate a heterogeneous distribution of $82 \mathrm{Mg}$ isotopes in the mantle induced by mantle metasomatism.

\section{2. Sample petrology}

85 Twenty five pyroxenite and two lherzolite xenoliths were selected for Mg isotopic 86 measurements to cover the wide range of texture, modal and compositional mineralogy of 87 a larger sample collection. They are generally very large and fresh (Fig. 1A), and can be 88 broadly divided into garnet-bearing and garnet-free groups. The garnet-bearing group 89 contains two lherzolites, 15 websterites and three clinopyroxenites, in order of 90 increasingly darker appearance. Some garnet pyroxenites form veins infiltrating the host 91 spinel lherzolites, while other discrete samples (without peridotite hosts) with a similar 92 mineralogy could be fragments from wider garnet pyroxenite veins. These xenoliths 93 consist mainly of olivine, garnet, clinopyroxene, orthopyroxene with accessory spinel 
94 (Fig. 1B; Table S1). The most prominent petrographic features of these xenoliths are the 95 secondary nature of the constituent garnet and its close association with spinel. Garnets 96 commonly form rims on spinels, giving rise to the typical spinel-cored garnets (Fig. 1C).

97 The observation that garnet gradually replaces spinel suggests garnet was formed at a 98 later stage, at the expense of spinel (Fig. 1D-G). Notably, the relic spinel cores display 99 embayed and amoeboidal grain boundaries (Fig. 1C), suggesting that garnets have grown 100 in the presence of melts (Keshav et al., 2007). Garnets also formed from the triple101 junctions of co-existing minerals and gradually occupy their grain boundaries, as well as 102 engulf adjacent olivine or pyroxene grains (Fig. 1H-J), until growing into noticeably large 103 grains that are much coarser than other co-existing mineral phases or typical garnets seen

104 in garnet peridotites (Fig. 1G). Moreover, different garnet grains are often connected to 105 each other, forming veins in the olivine-pyroxene matrix, and showing elongation along 106 the vein direction (Fig. 1A).

107 While garnet is usually in reacting relationship to olivine and pyroxene, olivine 108 and pyroxene grains frequently show triple-junction contact, implying textural 109 equilibrium (Fig. 1K and M). Olivines are typically subhedral granular or elongated 110 under deformation. Some olivine grains also occur as anhedral relic phase in garnets or as 111 elongated crystals that gradually taper out between garnets and pyroxenes, suggesting 112 their possible role as a reactant in the garnet-forming reaction. Pyroxenes are generally 113 the dominant phase and occur as large tabular or polygonal grains (Fig. H and K). Both 114 olivine and orthopyroxene are often strained and exhibit multiple kink bands (Fig. 1K). 115 Undulatory extinction is occasionally observed in orthopyroxene as well. These 116 deformation features are consistent with plastic deformation at high temperature and 117 suggestive of a non-cumulative origin for these xenoliths (e.g. Ionov et al., 2005). 118 Trapped melt/fluid inclusions are commonly found in pyroxenes (Fig. 1L) and some 119 clinopyroxene grains have sieved rims with irregular glass films. In addition to these 120 common mineral phases, glass veins with sparse tiny metasomatic phlogopite and apatite 121 are observed (Fig. 1N - P).

122 The garnet-free group includes three green $\mathrm{Cr}$ websterites (ranging from 123 clinopyroxene-rich to orthopyroxene-rich in composition), one dark Al websterite, two 124 grayish green $\mathrm{Cr}$ clinopyroxenites, and one dark brown orthopyroxenite. Following the 
125 classification proposed by Wilshire and Shervais (1975), the $\mathrm{Cr}$ websterites are

126 characterized by the presence of emerald green $\mathrm{Cr}$-diopside, while diopsides in the $\mathrm{Al}$ 127 websterite are more enriched in Al. The two types of pyroxenes have a similar grain size 128 in two $\mathrm{Cr}$ websterites while clinopyroxene is much smaller and less abundant in the 129 orthopyroxene-rich $\mathrm{Cr}$ websterite and in the orthopyroxenite.

130 In addition to these xenoliths, two Hannuoba basalts were also analyzed to help 131 identify the presence of subducted crustal material in the Hannuoba mantle, as eastern 132 China basalts that carrying a light $\delta^{26} \mathrm{Mg}$ signal were generally thought to have had their 133 mantle source been modified by carbonatitic melts released from subducted oceanic crust 134 (Yang et al., 2012; Huang et al., 2015). Although metamorphosed oceanic crust (i.e., 135 eclogites) have shown highly heterogeneous, and generally light, $\mathrm{Mg}$ isotopic 136 composition (Wang et al., 2012), it still needs to be tested to what extent carbonatite 137 metasomatism can shift the $\mathrm{Mg}$ isotopic composition of mantle rocks as previous 138 measurements on carbonate-metasomatized peridotites did not show noticeable deviation 139 from mantle value (Handler et al., 2009; Teng et al., 2010). Due to the lack of strongly 140 carbonatite-metasomatized sample in our sample collection from Hannuoba, a 141 carbonatite-metasomatized garnet lherzolite from western Qinling, China, was analyzed. 142 It has carbonatite-like trace element patterns and $\mathrm{Sr}-\mathrm{Pb}$ isotopic composition and displays 143 positive $\mathrm{Sr}$ and $\mathrm{Ba}$ anomalies, attesting to the influence of carbonatite metasomatism, 144 while their high $\mathrm{Nb}$ and $\mathrm{Ta}$ concentrations suggest the influence of subducted 145 components (Su et al., 2012b).

\section{3. Methods for Mg isotopic analysis}

148 Chemical separation of $\mathrm{Mg}$ and subsequent isotopic analyses were performed at 149 the University of Arkansas, Fayetteville, following the method developed in Teng et al. 150 (2007). All chemical procedures were performed in a metal-free clean laboratory. Pre151 cleaned Savillex Teflon ${ }^{\circledR}$ screw-top beakers were used exclusively during chemical 152 separation and instrumental analyses.

153 The whole-rock powders used for major and trace elemental analyses were used 154 here for $\mathrm{Mg}$ isotopic measurements. In addition, optically clean mineral fragments were 155 handpicked under a binocular microscope to $>99 \%$ purity and triple cleaned with Milli- 
$156 \mathrm{Q}^{\circledR}$ water in an ultra-sonic bath $(\geq 10$ minutes per wash). The mineral and whole-rock 157 samples were attacked sequentially with Optima-grade concentrated $\mathrm{HF}-\mathrm{HNO}_{3}, \mathrm{HNO}_{3}$ $158 \mathrm{HCl}$ and $\mathrm{HNO}_{3}$, following the method detailed in Yang et al. (2009). An ultrasonic bath 159 was used to accelerate dissolution by disrupting sample size and hence increasing the 160 solid-acid interface. All samples were finally taken up in $1 \mathrm{~N} \mathrm{HNO}_{3}$ and loaded onto pre161 cleaned Bio-Rad cation-exchange resin (AG50W-X8, 200-400 mesh). Matrix elements 162 were eluted away in the first $16 \mathrm{~mL}$ of $1 \mathrm{~N} \mathrm{HNO}_{3}$, and $\mathrm{Mg}$ was collected in the following $16319 \mathrm{~mL}$ of the same acid. This purification procedure was repeated twice to ensure 164 maximum elimination of the matrix. The total procedural blank was < $10 \mathrm{ng}$, representing $165<0.1 \%$ of Mg loaded onto the column (Teng et al., 2010).

166 Magnesium isotopic ratios were measured on a $\mathrm{Nu}$ Plasma MC-ICPMS. Sample 167 solutions were introduced into the ion source with "wet" plasma condition, which has 168 been demonstrated to be more resistant to matrix effects and concentration mismatch than 169 the "dry" plasma introduction for Mg isotopic analysis (Teng and Yang, 2014). Matching 170 in acid molarity and $\mathrm{Mg}$ concentration among all analyzed solutions are crucial for 171 accurate $\mathrm{Mg}$ isotopic analyses (Teng and Yang, 2014). Therefore, all the sample and 172 standard solutions were prepared at the day of measurement using the same batch of $3 \%$ 173 Optima-grade $\mathrm{HNO}_{3}$. Also, the standard solutions were prepared in the same numbers, 174 container type, and liquid volume to those of sample solutions, to minimize the effect of 175 evaporation during a batch run. The intensity matching between samples and standards 176 were kept within $95 \%$ to avoid instrumental bias in $\mathrm{Mg}$ isotopic measurement (Teng and 177 Yang, 2014). At a typical Mg concentration of $300 \mathrm{ppb},{ }^{24} \mathrm{Mg}$ background is negligible $(<$ $17810^{-4} \mathrm{~V}$ ) compared to sample signals (3 to $4 \mathrm{~V}$ ). The instrumental fractionation was 179 corrected by sample-standard bracketing technique assuming a linear mass fractionation 180 drift during a batch run. All Mg isotope data are reported in delta ( $\delta$ ) notation on DSM-3 181 scale (Galy et al., 2003). The $\delta^{\mathrm{X}} \mathrm{Mg}$ values reported represent parts per thousand (\%) 182 deviations of a ratio relative to the average of the two standard ratios measured before 183 and after:

$$
\delta^{\mathrm{X}} \mathrm{Mg}=10^{3} \times\left\{\frac{\left({ }^{\mathrm{X}} \mathrm{Mg} /{ }^{24} \mathrm{Mg}\right)_{\text {sample }}}{\left({ }^{\mathrm{X}} \mathrm{Mg} /{ }^{24} \mathrm{Mg}\right)_{\text {DSM3 }}}-1\right\},
$$

185 where $\mathrm{X}$ refers to mass 25 or 26. 
The accuracy of $\mathrm{Mg}$ isotopic analysis was assessed in two ways. First, five international rock standards (DTS-1, PCC-1, BHVO, MAG-1, and Murchison meteorite) 188 were processed through the same procedure as all the unknown samples. They yielded $\delta^{26} \mathrm{Mg}$ values comparable to previously published data (Table 1 ), and thus provide warranty for our entire analytical procedure, including sample digestion, chemical separation and mass spectrometry. Then, two in-house standards (e.g., Kilbourne Hole olivine and Hawaiian seawater) were processed through column chemistry and analyzed

193 along with unknown samples during each batch run. The results of these in-house standards also agree with literature values (Table 1).

The analytical reproducibility is also critical, particularly in that some data obtained in this study deviate significantly from previously published values for the same type of minerals or rocks, and there is no literature reference for mantle pyroxenites and pyroxenitic garnets. Analytical results from repeat analyses of the same sample, from dissolution or column chromatography to isotopic measurement, were reproduced within $200 \pm 0.05 \%$ ( $2 \mathrm{SD}$ ) for $\delta^{26} \mathrm{Mg}$ (Tables 2 ). Therefore, the reproducibility during the analytical 201 period of this study is consistent with the conservative long-term (four-year) external 202 precision for $\mathrm{Mg}$ isotopic data reported from this laboratory $\left(< \pm 0.07 \%\right.$ for $\delta^{26} \mathrm{Mg}$, Teng 203 et al., 2015).

\section{Results}

Major and trace element data for the bulk Hannuoba xenoliths are reported in

207 Tables S2 and S3, respectively. Their average mineral compositions are presented in 208 Tables S4-8. The temperature and pressure estimates based on different 209 geothermobarometers are provided in Table 3. Relevant analytical methods are also 210 provided in the supplementary materials.

\section{4.1. Whole-rock major and trace element compositions}

212 The Hannuoba pyroxenites and garnet-bearing lherzolites display much wider 213 compositional variations compared with spinel-facies peridotites and wehrlites (Fig. 2), 214 reflecting their more varied mineralogy (Fig. 2C). While they are more enriched in 215 fusible components than peridotites by having higher $\mathrm{Al}_{2} \mathrm{O}_{3}$ (5.41-14.4 wt.\%) and $\mathrm{CaO}$ 
216 (1.35-21.6 wt.\%) (Fig. 2A and B), their Mg\# and Ni contents are much higher than those

217 of basalts (Fig. 2D). In particular, the garnet-bearing group extends from that close to the 218 peridotite field to $\mathrm{Si}$ - and Al-rich field approaching the Jiaohe pyroxenites (Fig. 2C), 219 which were interpreted as remnants of subducted oceanic crust (Yu et al., 2010). The two 220 Hannuoba basalts analyzed here fall within the range of published basalt data (Fig. 2).

221 One of them belongs to the tholeiitic group while the other with slightly higher alkali 222 content and lower $\mathrm{SiO}_{2}$ belongs to the alkali group based on the TAS diagram (Total 223 Alkalis vs. $\mathrm{SiO}_{2}$, Le Bas et al., 1986, not shown).

224 Most of the xenoliths have higher rare earth element (REE) contents than the 225 spinel peridotite residuals reported in the literature, except the orthopyroxenite that falls 226 within the spinel peridotite field (Fig. 3A and C). The REE patterns of garnet-bearing 227 lherzolites and pyroxenites are characterized by flat heavy REE and variable light REE 228 (LREE), ranging from LREE-enriched to LREE-depleted to others having flat patterns. 229 The two garnet-bearing lherzolites and a $\mathrm{Cr}$ websterite display U-shaped REE patterns 230 (Fig. 3A and C) that are also typical for spinel lherzolites (e.g. Rudnick et al., 2004), 231 which is generally interpreted as the result of re-introduction of highly incompatible 232 elements by metasomatic melts after partial melting (Coltorti and Grégoire, 2008). These 233 garnet-bearing xenoliths are also distinctive in their enrichment in fluid-mobile large ion 234 lithophile element (LILE) concentrations with significant peaks at $\mathrm{Pb}(0.2$ to $0.9 \mathrm{ppm})$ 235 and $\mathrm{Sr}$ (41 to $368 \mathrm{ppm}$ ) in the primitive mantle-normalized trace element diagrams with 236 no obvious Eu anomaly presented (Fig. 3B and D). The two garnet-free $\mathrm{Cr}$ 237 clinopyroxenites contain the highest $\sum \operatorname{REE}(65.2$ and $105 \mathrm{ppm})$ among all the samples 238 and show convex-upwards REE patterns (Fig. 3C), which is commonly observed for 239 cumulative pyroxenites (Frey and Prinz, 1978). The Al websterite exhibits a similar REE 240 pattern with the apex shifts from Ce to $\mathrm{Nd}$ (Fig. 3C).

\section{4.2. Mineral chemistry}

243 Except spinel, all the other constituent minerals exhibit a compositional affinity to 244 non-cratonic peridotites, and are significantly different from those of pyroxenite 245 cumulates worldwide (Fig. 4A and B). In addition, only olivine in the garnet-bearing 246 xenoliths displays clear compositional zoning (Fig. 1M), with a Mg-rich core $(\mathrm{Mg \#}=$ 
24786.3 to 91.0$)$ and a Fe-rich rim $(\mathrm{Mg} \#=82.1$ to 90.8$)$. Up to $\sim 500 \mu \mathrm{m}$ wide zoning has 248 been observed in back-scattered electron images, and the intra-grain differences in Mg\# 249 can be as large as 6.5 , attesting to the major element disequilibrium within individual 250 grains.

All the garnets in samples studied here were replaced by kelyphite consisting of 252 fine-grain intergrowths of spinel and plagioclase (Liu et al., 2005), although fresh relic 253 garnets have rarely been reported (Chen et al, 2001; Liu et al., 2005). These kelyphites

254 still possess an almost identical bulk chemical composition to garnets, with only few 255 analyses yielding higher contents of $\mathrm{Na}_{2} \mathrm{O}$, suggesting alkali ingress from metasomatic 256 melts (Liu et al., 2010c). Garnets are rich in pyrope end-member $\left(\operatorname{Pyr}_{69.0-74.9}, \mathrm{Alm}_{11.8-18.7}\right.$, $257 \mathrm{Gro}_{10.1-16.8}$ ), consistent with their relatively high $\mathrm{Mg \#} \mathrm{(78.8} \mathrm{to} \mathrm{85.8)} \mathrm{and} \mathrm{mantle} \mathrm{origin.}$ 258 Their $\mathrm{CaO}$ and $\mathrm{Cr}_{2} \mathrm{O}_{3}$ contents fall within the websteritic field (Sobolev et al., 1973) (Fig. $2594 \mathrm{C})$.

260 Pyroxenes show limited compositional variation in the Wo-En-Fs quadrilateral 261 (Fig. 5). Clinopyroxenes have an average composition of $\mathrm{Wo}_{45.6} \mathrm{En}_{48.9} \mathrm{Fs}_{5.52}$, and 262 concentrated on the boundary between diopside and augite while orthopyroxenes range in 263 composition from enstatite to bronzite $\left(\operatorname{En}_{85.6}\right.$ to $\left.E_{90.2}\right)$. In contrast to the Cr-rich spinels 264 commonly found in mantle xenoliths, spinels from the xenoliths analyzed here are $\mathrm{Cr}$ 265 poor and Al-rich, with moderate Mg\# (70.8 to 80.3). Their Cr\# values (1.46 to 15.6) are 266 close to the low $\mathrm{Cr} \#$ end of non-cratonic peridotitic spinels and spinels found in the 267 reaction zone between a lherzolite and its host basalt, suggesting late-stage modification 268 (Zhang et al., 2007a) (Fig. 4D).

269 Garnet-free pyroxenites consist mainly of pyroxene with minor spinel. 270 Clinopyroxenes are all diopside with slightly different compositions (Fig. 5). Those from 271 the $\mathrm{Cr}$ websterites are $\mathrm{Cr}$-rich ( $\mathrm{Wo}_{45.0-49.1} \mathrm{En}_{42.6-49.8} \mathrm{Fs}_{5.16-9.12}$, with $\mathrm{Cr}_{2} \mathrm{O}_{3}$ up to 1.1 wt.\%), 272 while those from the Al websterite are more Al-, Fe-, and Na-rich $\left(\mathrm{Wo}_{48.0} \mathrm{En}_{41.2} \mathrm{Fs}_{10.8}\right)$, 273 and those from the clinopyroxenites are Ca-rich $\left(\mathrm{Wo}_{50.7} \mathrm{En}_{43.0} \mathrm{Fs}_{6.3}\right)$. Orthopyroxenes 274 range from enstatite to bronzite, with those from the $\mathrm{Cr}$ websterites being more $\mathrm{Mg}$-rich 275 (Fs = 9.48-20.1) and those from the Al websterite being more Fe-rich (Fs = 24.3). In 276 addition, clinopyroxenes from the clinopyroxene-rich $\mathrm{Cr}$ websterites fall within the 277 peridotite compositional field, whereas those from the Al websterite, the orthopyroxenite, 
278 and the orthopyroxene-rich $\mathrm{Cr}$ websterite falls along the metasomatic trend defined by

279 Iran pyroxenites that formed via interaction between lithospheric mantle and slab melts 280 (Fig. 3B) (Su et al., 2014). Spinels from the Cr websterites have higher Cr\# (26.8 and 281 10.3) and $\mathrm{Mg} \#$ (72 and 59.6) than those from the $\mathrm{Al}$ websterites $(\mathrm{Cr} \#=1.02, \mathrm{Mg} \#=56.4)$.

\subsection{Temperature and pressure estimates}

Equilibrium partitioning of $\mathrm{Mg}-\mathrm{Fe}$ among clinopyroxene, orthopyroxene and olivine, as indicated by the 1:1 linear correlations between the Mg\# of these three minerals (Fig. 6A and B) (Keshav and Sen, 2004), and their general straight and smooth

287 grain boundaries, permits temperature estimates for the Hannuoba xenoliths.

288 Temperatures estimated from five different thermometers agree within $50^{\circ} \mathrm{C}$ (Table 3).

289 This consistency in turn reflects equilibrium distribution of relevant elements among the

290 co-existing minerals. The calculated temperatures and pressures for most garnet-bearing

291 xenoliths fall within the ranges of 900 to $1040^{\circ} \mathrm{C}$, and 1.5 to $2.0 \mathrm{GPa}$, respectively (Table

292 3), consistent with previous estimates (e.g. Chen et al., 2001; Xu, 2002; Liu et al., 2003,

293 2005, 2010; Fan et al., 2005) and overlap with the range for Hannuoba spinel peridotites

294 (839 to $1072^{\circ} \mathrm{C}$, Chen et al., 2001, Rudnick et al., 2004), while are higher than the

295 Hannuoba garnet-bearing mafic granulites $\left(768-835^{\circ} \mathrm{C}\right.$, Liu et al., 2010b). Garnet-free

296 pyroxenites generally yield lower equilibrium temperatures $\left(844-868^{\circ} \mathrm{C}\right)$, except the $\mathrm{Cr}$ -

297 rich websterite that has an equilibrium temperature $\left(1039^{\circ} \mathrm{C}\right)$ similar to the peridotites.

298 These estimates also agree with the estimates reported by $\mathrm{Xu}$ (2002) and Chen et al. 299 (2001).

\subsection{Magnesium isotopic compositions}

302 Magnesium isotopic compositions of the garnet-bearing xenoliths are reported in 303 Table 4 for both whole rocks and mineral separates. Calculated inter-mineral 304 fractionations are given in Table 5 along with mineral equilibration temperature derived 305 from Wells (1977) geothermometer, as this thermometer is commonly used for 306 pyroxenites (e.g., Ying et al., 2013, Su et al., 2014) and yields temperature estimates that 307 are in good agreement with other calibrations. Mg isotopic compositions of the garnet- 
308 free xenolith group and the two Hannuoba basalts, as well as the carbonatite309 metasomatized garnet peridotite from Qinling are presented in Table 6, along with their 310 inter-mineral fractionation and equilibrium temperatures, if applicable. All our samples

311 (including reference materials) fall on a mass-dependent isotope fractionation line, with $312 \delta^{25} \mathrm{Mg}$ being 0.516 times $\delta^{26} \mathrm{Mg}\left(\mathrm{R}^{2}=0.99\right)$; therefore, only $\delta^{26} \mathrm{Mg}$ values are used in the 313 following and discussion sessions.

\section{4.4.1. Whole-rocks}

316 The xenoliths and basalts analyzed in this study have shown a more scattered 317 isotopic distribution than the normally homogeneous mantle peridotites and oceanic 318 basalts, with most samples shifting to the lighter-than-mantle side (Fig. 7A). The two 319 Hannuoba garnet-bearing lherzolites and the one from western Qinling have similar $320 \delta^{26} \mathrm{Mg}$ values of $-0.33 \%$ to $-0.39 \%$, slightly lighter than the three literature data ( -0.21 to $321-0.23 \%$, Teng et al., 2010; Pogge von Strandmann et al., 2011). The $\delta^{26} \mathrm{Mg}$ values of 12 322 garnet websterites range from -0.43 to $-0.10 \%$ and those of the three garnet 323 clinopyroxenites vary from -0.48 to $-0.18 \%$.

324 In contrast to the large variation displayed by the garnet-bearing xenoliths, both 325 the $\mathrm{Cr}$ and $\mathrm{Al}$ websterite, and the orthopyroxenite have mantle-like $\delta^{26} \mathrm{Mg}$ values $(-0.17$ 326 to $-0.32 \%$ ). The two garnet-free clinopyroxenites yield $\delta^{26} \mathrm{Mg}$ values of $-1.26 \%$ and 327 1.51\%, which are the lightest $\delta^{26} \mathrm{Mg}$ values find in this study and reported in the 328 literature for mantle rocks. The two Hannuoba basalts yield $\delta^{26} \mathrm{Mg}$ of $-0.35 \%$ and $3290.50 \%$, falling into the range reported for the nearby Taihang basalts $(-0.30$ to $-0.54 \%$, 330 Yang et al., 2012).

\section{4.4.2. Mineral separates (olivine, Cpx, Opx, and garnet)}

333 The 69 mineral separates in the garnet-bearing xenoliths span a total $\delta^{26} \mathrm{Mg}$ range 334 of $0.80 \%$, from $-0.75 \%$ in garnet to $+0.05 \%$ in olivine. Among all the mineral phases, 335 garnets show the widest variation, from -0.37 to $-0.75 \%$, and are systematically lighter 336 than co-existing olivine and pyroxene, which have $\delta^{26} \mathrm{Mg}$ values concentrated in the 337 mantle range (Fig. 7B). The $\delta^{26} \mathrm{Mg}$ values of olivine vary from -0.40 to $+0.05 \%$, while 
338 those of clinopyroxene and orthopyroxene exhibit a similar range of -0.46 to $+0.02 \%$ and $339-0.37$ to $0 \%$, respectively, comparable to published data (e.g., Handler et al., 2009; Yang 340 et al., 2009; Young et al., 2009; Huang et al., 2011; Liu et al., 2011; Xiao et al., 2013).

341 The average mineral $\delta^{26} \mathrm{Mg}$ values based on all analyses is $-0.22 \pm 0.24(\mathrm{n}=20,2 \mathrm{SD})$ for 342 olivine, $-0.21 \pm 0.20(n=19,2 S D)$ for clinopyroxene, and $-0.21 \pm 0.21(n=15,2 S D)$ for 343 orthopyroxene.

344 The four clinopyroxene and orthopyroxene pairs from the garnet-free websterites

345 and the orthopyroxene from the orthopyroxenite have mantle-like $\delta^{26} \mathrm{Mg}$ values, with $346 \delta^{26} \mathrm{Mg}$ varying from -0.24 to $-0.33 \%$ in clinopyroxene and -0.21 to $-0.28 \%$ in 347 orthopyroxene. Clinopyroxenes from the two clinopyroxenites are much lighter than the 348 normal mantle clinopyroxene range (-1.34\%o and $-1.47 \%$ ), whereas are consistent with 349 their extremely light whole-rock $\delta^{26} \mathrm{Mg}$ values.

\section{Discussion}

352 Our data show that the pyroxenite xenoliths have variable $\mathrm{Mg}$ isotopic 353 compositions, which might be genetically linked to different episodes of melt activity in 354 the Hannuoba lithospheric mantle. The broad zircon age spectrum and large elemental 355 and isotopic variation in $\mathrm{Sr}-\mathrm{Nd}-\mathrm{Pb}-\mathrm{Li}-\mathrm{Fe}$ for peridotitic and pyroxenitic xenoliths 356 revealed that the mantle beneath this region has been subjected to multi-stage 357 modification by both crustal- and mantle-derived melts (Song and Frey, 1989; Tatsumoto 358 et al., 1992; Liu et al., 2004, 2005, 2010c; Rudnick et al., 2004; Tang et al., 2007; Choi et 359 al., 2008; Zhang, 2009; Zheng et al., 2009; Zhao et al., 2010). In this section, we first 360 explore the genetic connection between the $\mathrm{Mg}$ isotopic composition of each pyroxenite 361 group and their corresponding origin. Then, we evaluate whether inter-mineral $\mathrm{Mg}$ 362 isotope partitioning within each xenolith group has reached equilibrium or not by 363 comparison with theoretical calculations and empirical data. When disequilibrium inter364 mineral fractionations are observed, their possible driving forces are examined. Finally, 365 we discuss the implications of $\delta^{26} \mathrm{Mg}$ variation in mantle pyroxenites on mantle $\mathrm{Mg}$ 366 isotopic heterogeneity. 


\subsection{Garnet-bearing lherzolites and pyroxenites}

\section{$369 \quad$ 5.1.1 Origin of garnet-bearing xenoliths}

The occurrence of garnet pyroxenite veins infiltrating the host peridotites establishes their formation at mantle depths, which is consistent with the temperatures

372 and pressure estimates of $\sim 1000^{\circ} \mathrm{C}$ and 1.5-2.0 Ga based on their mineral compositions.

373 The bulk rocks do not share a common composition with MORB (Fig. 2) and lack the 374 positive Eu anomalies (Fig. 3A) that are typical for oceanic gabbros (e.g., Stracke et al., 375 2003). These characteristics rule out their origin as recycled oceanic lithosphere. Their major element compositions also plot off the extension trends between the Hannuoba peridotites and calculated equilibrium melts (Fig. 2A and B), and their $\delta^{26} \mathrm{Mg}$ range is much wider than that of the normal mantle, arguing against their origin as in situ melting of the host peridotites suggested by Chen et al. (2001). Their major constituent minerals show a strong mantle-affinity while are significantly different from those in pyroxenite cumulates worldwide (Fig. 4A and B). The lack of convex-upward REE patterns that are typical for cumulative pyroxenites (Frey and Prinz, 1978) and the presence of deformation features are also inconsistent with a cumulate origin (Ionov et al., 2005).

Liu et al. (2005) alternatively proposed a replacive origin for these garnet-bearing pyroxenites. In their model, peridotites are converted to garnet pyroxenites by reaction with melts from ancient subducted oceanic slab, which results in formation of pyroxene and garnet at the expense of olivine (Yaxley and Green, 1998; Rapp et al., 1999). This 388 metasomatic origin explains the decoupled major-trace elemental features which show 389 that while the whole rocks are enriched in highly incompatible elements (e.g., $\mathrm{Rb}, \mathrm{Ba} \mathrm{Sr}$ 390 and $\mathrm{Pb}$ ) (Fig. 3B) with some showing relatively high ${ }^{87} \mathrm{Sr} /{ }^{86} \mathrm{Sr}$ for their $\varepsilon_{\mathrm{Nd}}$ (Xu et al.,

391 2002), their major mineral phases still preserve peridotite affinities (Fig. 4A and B). Later 392 experimental studies (Wang et al., 2010; Zhang et al., 2012) have successfully 393 reproduced similar garnet pyroxenites by reacting a Hannuoba spinel lherzolite with a 394 quartz eclogite from central China. Subsequent finding of $315 \mathrm{Ma}$ igneous zircons 395 together with the record of coeval subduction-related magmatism (Zhang et al., 2009) 396 provided further support to this explanation. 


\subsubsection{Whole-rock Mg isotopic variation}

Building on previous discussions, the new $\mathrm{Mg}$ isotopic data obtained here further substantiate the replacive origin for these garnet-bearing xenoliths and the critical role of recycled oceanic crust in forming them. In view that the majority of olivine and pyroxene still preserve their mantle-like $\delta^{26} \mathrm{Mg}$, the formation of secondary isotopically light garnet thus requires addition of light $\mathrm{Mg}$ into the bulk rocks from an external source. The isotopically light alkali basalts that host the xenoliths might be a possible candidate. However, lighter $\mathrm{Mg}$ isotopes diffuse faster than their heavy counterparts and they preferentially diffuse toward the hot end along a thermal gradient (Richter et al., 2009 and references therein). Therefore, diffusion of $\mathrm{Mg}$ from the xenoliths into their host magmas during magma ascent will result in depletion of light isotopes in these xenoliths, which is opposite to our observation here. In addition, given a typical ascent rate for xenolith-bearing alkali basalts of about 0.1 to $10 \mathrm{~m} / \mathrm{s}$ (Spera, 1984), and an entrained depth of approximately $60 \mathrm{~km}$ for the xenoliths in this study, the magma should have reached the surface in hours or days. Likewise, basaltic flows commonly cool on the order of weeks (Flynn et al., 1994). The rapid eruption and cooling of alkali basalts thus precludes extensive interaction between the xenoliths and the host magma. Therefore, the garnets and their host xenoliths must have acquired their Mg isotopic characteristics before entrainment by the host magma.

418 presence of subducted slab in their mantle source, which is a common explanation for the 419 isotopically light basalts found on eastern China (Fig. 7B) (e.g. Yang et al., 2012; Huang 420 et al., 2015). This argument is mainly based on the finding of cratonic eclogites that are 421 generally depleted in heavy $\mathrm{Mg}$ isotopes (Wang et al., 2012), which were taken as 422 evidence for incorporation of sedimentary carbonates during low-temperature alteration 423 of oceanic crust. The light $\mathrm{Mg}$ in carbonates can be incorporated into silicates by 424 metamorphic de-carbonation or fluid-mediated isotopic exchange (Wang et al., 2014a). 425 The major element compositions of these garnet-bearing xenoliths lie on the binary 426 mixing trends between mantle peridotites and recycled oceanic crustal pyroxenites (Fig.

427 2). Their $\mathrm{Mg}$ isotopic compositions can also be explained by the triangle defined by 428 mixing between oceanic crust, as represented by the cratonic eclogites (Wang et al., 2012) 
and NCC peridotites (Teng et al., 2010) (Fig. 8). The presence of altered subducted slab

430 and sediments in the mantle beneath the Hannuoba region may also contribute to the low

$431 \delta^{7} \mathrm{Li}$ signature that characterize Hannuoba peridotites (Tang et al., 2007), and the

432 formation of Al-rich sapphirine in Hannuoba mantle clinopyroxenites ( $\mathrm{Su}$ et al., 2012a).

\subsubsection{Inter-mineral $\mathrm{Mg}$ isotope fractionation}

Mantle minerals are generally found to be in isotopic equilibrium since high temperature promotes isotope diffusion (Urey, 1947). To reach equilibrium, heavy isotopes are preferentially concentrated in minerals with stronger chemical bonds due to

438 their higher vibrational frequency and therefore greater energy reduction upon isotope 439 exchange (Bigeleisen, 1965). Since $\mathrm{Mg}$ only occurs with one oxidation state $(+2)$ in 440 common minerals, the key factor determining $\mathrm{Mg}-\mathrm{O}$ bond strength is the coordination 441 number of $\mathrm{Mg}$ in different minerals. Within a mineral class (e.g., silicates, carbonates, 442 oxides), mineral with higher coordination sites for $\mathrm{Mg}^{2+}$ allows a larger $\mathrm{Mg}^{2+}$ effective 443 ionic radii, therefore longer and weaker $\mathrm{Mg}$-O bonds, which favors lighter $\mathrm{Mg}$ isotopes 444 (see Young et al., 2015 for a thorough discussion).

445 Each $\mathrm{Mg}^{2+}$ is bonded to six neighboring oxygen anions in the predominant upper 446 mantle minerals (olivine, clinopyroxene, and orthopyroxene) with a similar bond strength.

447 Therefore, only limited fractionation occur between them, which is thought to result from 448 the subordinate, but stronger, $\mathrm{Mg}-{ }^{\mathrm{III}} \mathrm{O}$ bonds in pyroxene than the $\mathrm{Mg}-{ }^{\mathrm{IV}} \mathrm{O}$ bonds in 449 olivine (Young et al. 2009, 2015; Liu et al., 2010a, 2011). The Mg isotope fractionation 450 between most co-existing pyroxene and olivine in this study is barely analytically 451 resolvable, with $\Delta^{26} \mathrm{Mg}_{\mathrm{Cpx}-\mathrm{Ol}}=\delta^{26} \mathrm{Mg}_{\mathrm{Cpx}}-\delta^{26} \mathrm{Mg}_{\mathrm{Ol}}=-0.06$ to $+0.08 \%$ ( $\left.\mathrm{n}=17\right), \Delta^{26} \mathrm{Mg}_{\mathrm{Opx}-}$

$452 \mathrm{Ol}=\delta^{26} \mathrm{Mg}_{\mathrm{Opx}}-\delta^{26} \mathrm{Mg}_{\mathrm{Ol}}=-0.02$ to $+0.09 \%$ ( $\left.\mathrm{n}=14\right)$, and $\Delta^{26} \mathrm{Mg}_{\mathrm{Cpx}-\mathrm{Opx}}=\delta^{26} \mathrm{Mg}_{\mathrm{Cpx}}-$ $453 \delta^{26} \mathrm{Mg}_{\mathrm{Opx}}=-0.08$ to $+0.05 \%$ o $(\mathrm{n}=14)$. The magnitude of this fractionation agrees with 454 published $\mathrm{Mg}$ isotope data on equilibrated peridotitic pyroxene and olivine (Handler et al., 455 2009; Yang et al., 2009; Chakrabarti and Jacobsen, 2010; Huang et al., 2011; Liu et al., 456 2011; Pogge von Strandmann et al., 2011; Xiao et al., 2013), and falls within the ranges 457 of DFPT calculation (Schauble, 2011; Huang et al., 2013), as well as the ranges defined 458 by empirical measurements (Liu et al., 2011a) (Fig. 10A and B). Therefore, these 
observations suggest a broad equilibrium $\mathrm{Mg}$ isotope fractionation between pyroxene and

460 olivine in these samples.

461 Compared to the 6-fold coordinated $\mathrm{Mg}$ in olivine and pyroxene, $\mathrm{Mg}$ is 8-fold 462 coordinated in garnet and 4-fold coordinated in spinel, respectively. Therefore, garnets

463 are enriched in light $\mathrm{Mg}$ isotopes while spinels have a greater affinity for heavy $\mathrm{Mg}$

464 isotopes. In addition, cation substitution has been suggested to exert a secondary control 465 on the Mg isotopic composition of spinel (Liu et al., 2011; Shauble, 2011; Xiao et al.,

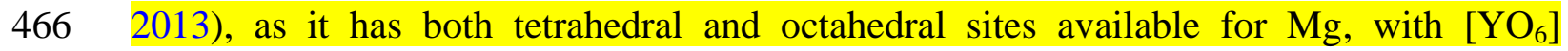
467 octahedrons sharing edge with each other. By contrast, $\mathrm{Mg}$ isotopic composition of garnet 468 should be much less sensitive to cation substation since its [ $\left.\mathrm{YO}_{6}\right]$ octahedrons are well 469 separated from each other by $\left[\mathrm{SiO}_{4}\right]^{4-}$ (Huang et al., 2013).

$470 \quad$ The isotopically lighter garnets found in the present study are thus consistent with 471 expectations from DFPT calculations (Huang et al., 2013) and measurements on 472 equilibrated eclogitic garnet and pyroxene (Li et al., 2011; Wang et al., 2012, 2014b). 473 Nonetheless, these garnets appear to be out of $\mathrm{Mg}$ isotopic equilibrium with co-existing 474 olivines and pyroxenes, as most of the observed fractionation factors are smaller than the 475 expected values at equilibrium (Fig. 10C). Based on the calculated clinopyroxene476 orthopyroxene mineral equilibrium temperature of $\sim 1000^{\circ} \mathrm{C}$, the empirical equilibrium 477 fractionation line would predict a clinopyroxene-garnet fractionation of $\sim 0.52 \%$ o $\mathrm{Li}$ et 478 al., 2011; Wang et al., 2012), while seven out of the 14 clinopyroxene-garnet pairs only 479 have fractionation between 0.36 and $0.42 \%$. If these values are taken as equilibrium 480 fractionations, then they would require the equilibrium temperatures to be higher than $4811380^{\circ} \mathrm{C}$ (Fig. 10D and E). Such high temperatures seem implausible for the Hannuoba 482 area, as both peridotites and pyroxenites have equilibrium temperatures around $1000^{\circ} \mathrm{C}$. 483 Additionally, over a limited temperature range, the fractionation between garnet and 484 olivine/pyroxene is highly variable, opposed to relatively constant fractionation as would 485 be expected for isotopic equilibrium (Fig. 10C). Therefore, we interpret that these garnets 486 have not yet reached isotopic equilibrium with the co-existing olivine and pyroxene.

\section{5.1.4. Mechanism of disequilibrium garnet-olivine/pyroxene} 489 fractionation 
The deviation of garnet-olivine/pyroxene fractionation from the equilibrium

491 values implies superimposition of kinetic processes on temperature-dependent $\mathrm{Mg}$ 492 isotope partitioning among these minerals. Since garnet accounts for a smaller modal 493 abundance than the predominant olivine and pyroxene, both of which have mantle-like $494 \delta^{26} \mathrm{Mg}$ and high $\mathrm{Mg}$ concentration, the kinetic effects should be more obviously seen in 495 garnets. Considering that $\delta^{26} \mathrm{Mg}$ in olivine and pyroxene are relatively invariant around 496 the normal mantle value, the reduced $\Delta^{26} \mathrm{Mg}_{\mathrm{Grt}-\mathrm{Ol} / \mathrm{Cpx} / \mathrm{Opx}}$ values are therefore mainly 497 caused by variably higher-than-equilibrium $\delta^{26} \mathrm{Mg}$ in garnets. Although there is no 498 published $\delta^{26} \mathrm{Mg}$ value on peridotitic garnet for comparison, The $\mathrm{Mg}$ isotopic 499 composition of garnets in the Hannuoba lherzolites and pyroxenites are much heavier 500 than garnets from cratonic eclogites formed at similar temperatures $(-0.61$ to $-0.72 \%$ in 501 Wang et al., 2012). For example, garnet as heavy as $-0.37 \%$ ( $\left(\delta^{26} \mathrm{Mg}\right)$ has been found in 502 this study.

503 Based on discussion in previous sections, the most relevant process accounting 504 for the disequilibrium inter-mineral fractionation is incomplete melt-rock interaction that 505 produced these garnets. The highly variable grain size (even within one hand specimen) 506 and modal abundance of garnet, together with their anhedral shape, are significantly 507 different from the relatively euhedral garnets commonly found in garnet peridotites and 508 eclogites. Petrographic observations of garnet replacing spinel (Fig. 1C-G) also suggest a 509 clear metasomatic origin for the garnets, instead of being the primary refractory phase 510 present in peridotites. Therefore, the later-formed garnets could partly inherit the heavy $511 \mathrm{Mg}$ isotope composition from its embedded isotopically heavy spinels, olivine, or 512 pyroxene grains, and therefore shifted their $\delta^{26} \mathrm{Mg}$ signals in the heavier direction. For 513 example, using the $\Delta^{26} \mathrm{Mg}_{\text {Spl-Ol }}$ vs. temperature calibration of Liu et al. (2011), spinel 514 equilibrated with the co-existing olivine in these garnet pyroxenites should be as heavy as $515+0.11 \%$. The broad negative correlation between $\mathrm{MgO}$ content in spinel and $\delta^{26} \mathrm{Mg}$ of 516 garnet supports this explanation (Fig. 10F). With progressively $\mathrm{Mg}$ lose from spinel to 517 the surrounding garnet, garnet exhibits an increasingly heavier $\delta^{26} \mathrm{Mg}$. Deviation from 518 this trend may suggest additional Mg input to garnet from olivine or pyroxene (Fig. 1H-J). 519 Similar incomplete isotopic exchange processes during rock-melt interaction have also 520 been invoked for the inter-mineral $\mathrm{Mg}-\mathrm{Fe}-\mathrm{Li}$ isotope disequilibrium found in peridotites 
521 from this craton (Tang et al., 2007, 2011; Yang et al., 2009; Zhang et al., 2010; Zhao et 522 al., 2010; Xiao et al., 2013).

523 Among the generally equilibrated olivine-pyroxene mineral pairs, samples D 01,

524 D 09 and D 7S seem to have an anomalous, larger fractionation, suggesting additional

525 influence of small-scale diffusional processes associated with the different $\mathrm{Mg}$ diffusivity 526 in these minerals. Sample D 7S has the lightest olivine (-0.40\%), clinopyroxene ($5270.46 \%$ ) , and orthopyroxene $(-0.37 \%$ ) , reflecting isotopic exchange with the inferred

528 isotopically light metasomatic melt, and the consequent reduced fractionation of garnet 529 relative to these minerals (e.g., $\Delta^{26} \mathrm{Mg}_{\mathrm{Cpx}-\mathrm{Grt}}=0.11 \%$ ). On the other hand, sample D 01 530 and D 09 documents the largest garnet-olivine/pyroxene fractionations in this study (e.g.,

$531 \Delta \Delta^{26} \mathrm{Mg}_{\mathrm{Ol}-\mathrm{Grt}}=-0.80 \%$ ), and their clinopyroxene-garnet fractionations are consistent with 532 equilibrium fractionation values. Therefore, the anomalously heavy $\delta^{26} \mathrm{Mg}$ in olivines $533\left(\delta^{26} \mathrm{Mg}=+0.05\right.$ and $\left.0.00 \%\right)$ may result from diffusional loss of light $\mathrm{Mg}$ isotopes to 534 garnet during re-equilibration with isotopically light garnet $\left(\delta^{26} \mathrm{Mg}=-0.75 \%\right.$ and $5350.76 \%$ ). This explanation is consistent with the faster diffusion of $\mathrm{Mg}$ in olivine than in 536 pyroxene (Chakraborty, 2010; Cherniak and Dimanov, 2010).

$537 \quad$ The $\mathrm{Mg}$ isotopic disequilibrium in the garnet-bearing pyroxenites suggests that 538 the melt-rock interaction that gave rise to these xenoliths probably occurred shortly 539 before their entrainment into the host basalts, especially considering the rapid diffusion 540 rate at mantle temperatures. For example, the self-diffusion coefficient of $\mathrm{Mg}$ in garnet $541\left(\sim 1.6 \times 10^{-15} \mathrm{~cm}^{2} / \mathrm{s}\right.$ at $1000^{\circ} \mathrm{C}$, Ganguly, 2010) predicts that $\mathrm{Mg}$ isotopic disequilibrium 542 may persist for $\sim 1.25$ Ma over $2.5 \mathrm{~mm}$ in width. Further constraints on the timing of 543 metasomatism may be provided by the olivine $\mathrm{Mg}$-Fe zoning present in some samples. 544 Taking the self-diffusion coefficient of $\mathrm{Mg}$ in olivine $\left(\sim 3.2 \times 10^{-15} \mathrm{~cm}^{2} / \mathrm{s}\right.$ at $1000^{\circ} \mathrm{C}$, 545 Chakraborty, 2010), the widest observed elemental zoning $(\sim 500 \mu \mathrm{m})$ would be 546 obliterated after $25 \mathrm{kyr}$. Therefore, these samples have probably been entrained by host 547 magma and transported to the surface not long after the garnets started to form, and thus 548 there was not sufficient time for the metasomatic garnets to reach isotopic equilibrium 549 with the primary olivine and pyroxenes.

550

$551 \quad 5.2$ Garnet-free websterites and orthopyroxenite 
Both $\mathrm{Cr}$ and $\mathrm{Al}$ pyroxenites are commonly found in alkali basalts along with 553 peridotites at Hannuoba and worldwide, either as composite xenoliths along with wall 554 rock peridotites or as discrete xenoliths. They are generally interpreted as crystallization 555 products of high-pressure basaltic melts as they pass through the lithospheric mantle 556 (Frey and Prinz, 1978; Irving, 1980; Xu, 2002). The Cr websterites and Al websterites, as 557 well as the orthopyroxenite analyzed here have mantle-like $\delta^{26} \mathrm{Mg}$ for both whole rocks (5580.18 to $-0.32 \%$ ) and minerals $(-0.21$ to $-0.33 \%$ ). In comparison, Hannuoba alkali basalts

559 have lighter $\delta^{26} \mathrm{Mg}$ values, and are markedly different in $\mathrm{Sr}-\mathrm{Nd}-\mathrm{Pb}$ isotopic composition 560 from the pyroxenites (Xu et al., 2002; Choi et al., 2008). Therefore, these xenoliths are 561 not co-genetic with their host basalts.

562 Lithium isotopic characteristics of the Hannuoba peridotites suggested 563 modification of the lithospheric mantle by asthenospheric melts (Tang et al., 2007), 564 which should have $\delta^{26} \mathrm{Mg}$ values identical to mantle peridotites, as sampled by global 565 oceanic basalts (Teng et al., 2010). Therefore, the $\mathrm{Cr}$ and $\mathrm{Al}$ websterites and the 566 orthopyroxenite analyzed here may represent different episodes of silicate melt injection 567 from the asthenosphere. $\mathrm{Xu}$ (2002) further suggested the involvement of recycled 568 continental crust in their parental magmas based on $\mathrm{Sr}-\mathrm{Nd}$ isotopic evidence. However, 569 limited contributions from continental crust are difficult to manifest themselves in $\mathrm{Mg}$ 570 isotopic compositions since crustal materials from continents have much lower $\mathrm{Mg}$ 571 concentration than the mantle and major Mg-bearing minerals in crustal rocks, including 572 biotite, hornblende and pyroxene, have a broadly mantle-like $\delta^{26} \mathrm{Mg}$ (Liu et al., 2010a).

\section{$574 \quad 5.3$ Garnet-free clinopyroxenites}

575 The two garnet-free clinopyroxenites analyzed here yield consistent light $\delta^{26} \mathrm{Mg}$ 576 values for both whole rocks and clinopyroxene fragments, which are also the lightest 577 values reported for mantle rocks so far. These extremely light $\mathrm{Mg}$ isotopic compositions 578 imply that their origin may be closely related to migration of carbonatitic melts in the 579 mantle, which are considered to be a major source of light Mg isotopes (Young and Galy, 580 2004). The two clinopyroxenites show the strongest enrichment in LREE among all the 581 pyroxenites studied here (Fig. 3C), with $\mathrm{La} / \mathrm{Yb}_{(\mathrm{N})}$ of 16.4 and 17.1. Their elevated $\mathrm{Zr} / \mathrm{Hf}$ 582 ratios (40.0 and 43.6) than the primitive mantle (36.2) (Fig. 3D) also suggest influence 
583 from carbonatites, which typically have high $\mathrm{Zr} / \mathrm{Hf}$ ratios (e.g., Rudnick et al., 1993).

584 More importantly, their low Ti/Eu ratios (Fig. 9) are consistent with their origin from 585 carbonatites (Rudnick et al., 1993; Coltorti et al., 1999). Clinopyroxenes with similar

586 composition have also been found in a few Hannuoba peridotite xenoliths ( $\mathrm{Yu}$ et al., 587 2006).

588 The presence of 48-64 Ma igneous zircons with pronounced enrichments in REE, 589 U, and Th in garnet pyroxenites (Liu et al., 2010c) and the discovery of carbonatite veins 590 cutting through host peridotites in the Hannuoba locality (Fan et al., 2010; Liu et al., 591 2010c) also support carbonatitic melt activity. Using the average Ti/Eu ratio of 592 carbonatite reported in Fan et al. (2010), the Mg isotopic composition of these 593 clinopyroxenites can be explained by binary mixing between mantle peridotites and 594 recycled carbonates with $\delta^{26} \mathrm{Mg}$ values of -3.00 to $-5.00 \%$ (Fig 11), which is the typical $595 \delta^{26} \mathrm{Mg}$ range of carbonate minerals (Young and Galy, 2004; Saenger and Wang, 2014). In 596 addition, the estimated compositions of hypothetical melts in equilibrium with the two 597 garnet-free clinopyroxenite xenoliths are similar to those of carbonatites from the North 598 China Craton (Ying et al., 2004). Therefore, we interpret these clinopyroxenites to be 599 formed by de-carbonation of migrating carbonatite melts, during which the isotopically 600 light $\mathrm{Mg}$ together with $\mathrm{Ca}$ from the carbonates will be incorporated into $\mathrm{Cpx}$ with the 601 release of $\mathrm{CO}_{2}$ (Yaxley et al., 1991, 1998; Rudnick et al., 1993; Knoche et al., 1999).

602 The carbonatitic melts gave rise to these light clinopyroxenites are more likely 603 sourced from recycled carbonate instead of asthenosphere, as experimental study of 604 Macris et al. (2013) has shown no analytically resolvable fractionation between 605 magnesite and olivine at $>800^{\circ} \mathrm{C}$, while the fractionation increases significantly at lower 606 temperature (e.g., $0.44 \%$ at $600^{\circ} \mathrm{C}$ ). This is consistent with the extremely light $\delta^{26} \mathrm{Mg}$ 607 values found in sedimentary carbonates (e.g., -5.54\%o, Wombacher et al., 2011). 608 Considering the geographical contiguity of the Hannuoba basaltic plateau to the Taihang 609 mountains and the similarity between the $\delta^{26} \mathrm{Mg}$ feature of the Hannuoba basalts to that 610 of the Taihang basalts, it is reasonable to infer that the Hannuoba lithospheric mantle has 611 likely been affected by the same carbonatitic metasomatic event. Moreover, the 612 isotopically light $\left(\delta^{26} \mathrm{Mg}=-0.39 \%\right.$ ) garnet lherzolite from western Qinling, which has 
613 subjected to strong carbonatite metasomatism, further confirms that the $\delta^{26} \mathrm{Mg}$ value of

614 mantle xenoliths can be lowered by reaction with carbonatite melts.

616 5.4. Implications on mantle $\delta^{26} \mathrm{Mg}$ heterogeneity

Previous Mg isotopic measurements on global peridotite xenoliths and oceanic

618 basalts have suggested a homogeneous mantle with respect to $\mathrm{Mg}$ isotope distribution

619 (Teng et al., 2010). However, there is now accumulating evidence for the existence of

620 local mantle domains with variable $\delta^{26} \mathrm{Mg}$ values that are thought to be the result of

621 interaction of normal $\delta^{26} \mathrm{Mg}$ mantle with migrating mantle melts/fluids (e.g., Yang et al.,

622 2012; Xiao et al., 2013; Huang et al., 2015). For example, the formation of different types

623 of Hannuoba mantle pyroxenites have been related to injection of melts with diverse

624 compositions into the subcontinental lithospheric mantle (SCLM), which register these

625 pyroxenites with different $\delta^{26} \mathrm{Mg}$ characteristics. Likewise, basalts erupted on continents

626 have frequently been found to be isotopically light (Yang et al., 2012; Huang et al., 2015;

627 and this study), in contrast to the homogeneous oceanic basalts (Teng et al., 2010). Since

628 partial melting and subsequent magma differentiation do not fractionate $\mathrm{Mg}$ isotopes

629 (Teng et al., 2007; 2010), the distinct $\delta^{26} \mathrm{Mg}$ signals carried by these continental basalts

630 should largely reflect their source heterogeneity. Soughing out the cause of these mantle

631 anomalies is thus critical for us to better understand the overall $\mathrm{Mg}$ isotopic composition

632 of the bulk silicate Earth.

633 The main feature distinguishes basalts generated at continental settings from those 634 at oceanic setting is the existence of a thick layer of SCLM on top of the asthenosphere, 635 which continuously digesting deep fluids/melts rising upward, replenishing the SCLM 636 with elements that were depleted due to earlier melting events. As a result, the SCLM 637 becomes a compositionally and lithologically heterogeneous reservoir (e.g., Brooks et al., 638 1976; Foley, 2008), contributing to continental magmatism by itself or together with 639 contributions from asthenospheric melts (e.g. McDonough et al., 1990 and reference 640 therein).

641 Recycled oceanic crusts have been considered as a primary contributor in the 642 origin of mantle anomalies as they can presumably carry the surface fractionation signals 643 imparted by seafloor alteration into the deep mantle (Yang et al., 2012). The recycled 
644 carbonated oceanic crust (-0.80 to $-0.14 \%$, Wang et al., 2012) and the overlying 645 sediments (-5.31 to -1.09\%, Young and Galy, 2004; Tipper et al., 2006a and b; Brenot et 646 al., 2008; Pogge von Strandmann, 2008; Hippler et al., 2009; Higgins and Schrag, 2010)

647 will thus become an anomalous $\mathrm{Mg}$ isotopic reservoir in the mantle. When partial melting 648 occurs, their heterogeneous $\mathrm{Mg}$ isotopic features may propagate into the ambient mantle 649 via a variety of metasomatic melts (e.g., carbonatite, carbonated silicate, and silicate 650 melts), which percolate and infiltrate the mantle wall-rock. The reaction products, as 651 represented by the diverse pyroxenites studied here, do exhibit a larger variation in $\delta^{26} \mathrm{Mg}$ 652 than peridotites, with $\delta^{26} \mathrm{Mg}$ values as low as $-1.51 \%$ having been found. Due to their 653 relatively lower solidus temperatures, pyroxenites will melt preferentially with a higher 654 melt-producing efficiency relative to the ambient peridotites. Therefore, when 655 contributed to continental magmatism, these heterogeneous pyroxenites will further 656 modify the $\mathrm{Mg}$ isotopic composition of mantle-derived volcanic rocks.

657 Subducted slabs have also been suggested in the source region of oceanic island 658 basalts (OIB). The absence of isotopically distinct OIB (Teng et al., 2010) may partially 659 due to the relatively cold and conductive nature of the SCLM, which keeps the 660 isotopically distinct domains last longer than those in the warmer sub-oceanic mantle, 661 where large-scale convection and continuous melting at the mid-ocean ridge tend to 662 eliminate all heterogeneities. In contrast, the long-term stability of the SCLM makes it an 663 increasingly heterogeneous reservoir through time. During eruption gaps of continental 664 magmatism, the SCLM can receive frequent melt modifications and consequently give 665 rise to new anomalous $\delta^{26} \mathrm{Mg}$ domains. In addition, oceanic-continental subduction is a 666 more frequent phenomenon than oceanic-oceanic subduction. Therefore, there might be 667 more relic slabs sitting beneath the continents. Frequent subduction from circum plates 668 around continents also makes the SCLM a relatively closed system, preventing the 669 isotopically heterogeneous domains from incorporating into the global mantle convection.

\section{6. Conclusions}

672 This study presents the first systematic dataset for high-precision $\mathrm{Mg}$ isotopic 673 analyses on mantle pyroxenites, coupled with their whole rock and mineral chemical 674 compositions. It highlights the potential of using $\mathrm{Mg}$ isotopes along with the traditional 
$675 \mathrm{Sr}-\mathrm{Nd}-\mathrm{Pb}$ isotopic systematics to trace melt activities in the mantle and the origin of 676 different types of mantle pyroxenites. The following conclusions can be drawn:

677 (1) The garnet-bearing lherzolites and pyroxenites, which represent reaction products

678 between peridotites and slab-derived melts, have variable $\delta^{26} \mathrm{Mg}$ ranging from -0.48 to $-0.10 \%(\mathrm{n}=17)$. There is a broad isotopic equilibrium among co-existing olivine, clinopyroxene, and orthopyroxene. However, garnet that is formed in a reacting

(2) Both garnet-free websterites and orthopyroxenite have $\delta^{26} \mathrm{Mg}$ values (-0.17 to $-0.32 \%$ ) relationship with spinel, olivine, and pyroxene has not yet reached $\delta^{26} \mathrm{Mg}$ equilibrium with these minerals. Contributions of heavy $\mathrm{Mg}$ isotopes from the enclosed spinel drove the $\delta^{26} \mathrm{Mg}$ of garnet to variably heavier values of 0.76 to $-0.37 \% 0(\mathrm{n}=15)$.

comparable to that of the mantle range $(-0.25 \pm 0.07 \%$, Teng et al., 2010). They may thus represent different episodes of asthenospheric melts injection into the subcontinental lithospheric mantle.

(3) The extremely light $\delta^{26} \mathrm{Mg}$ values exhibited by the two garnet-free clinopyroxenites imply an episode of carbonatitic melt activity. The carbonatitic melts are likely to have been involved in the mantle source of Hannuoba alkali basalt, which also exhibits a light $\mathrm{Mg}$ isotopic composition.

\section{Acknowledgements}

695 analytical and laboratory assistance. We are also grateful to Aaron Brewer, Anthony J.

696 Irving, Scott Kuehner, Yang Sun and Shui-Jiong Wang for stimulating discussion. The 697 manuscript has been greatly benefited from comments by C.A. Macris and two 698 anonymous reviewers; editorial handling by Shichun Huang is also much appreciated. 699 This research has been financially supported by National Science Foundation grants of 700 China (91214293 and 91014007), National Science Foundation of America (EAR701 0838227, EAR-1056713 and EAR-1340160), and 2014 graduate student research grant 702 from the Geological Society of America. 


\section{REFERENCES}

Adam, J. and Green, T. (2001) Experimentally determined partition coefficients for minor and trace elements in peridotite minerals and carbonatitic melt, and their relevance to natural carbonatites. Eur. J. Mineral. 13, 815-827.

Allègre, C.J. and Turcotte, D.L. (1986) Implications of a two-component marble-cake mantle. Nature 323, 123-127.

Anders, E. and Grevesse, N. (1989) Abundances of the elements: Meteoritic and solar. Geochim. Cosmochim. Acta 53, 197-214.

Anderson, D.L. (2005) Large igneous provinces, delamination, and fertile mantle. Elements 1, 271-275.

Basu, A.R., Junwen, W., Wankang, H., Guanghong, X. and Tatsumoto, M. (1991) Major element, $\mathrm{REE}$, and $\mathrm{Pb}, \mathrm{Nd}$ and $\mathrm{Sr}$ isotopic geochemistry of Cenozoic volcanic rocks of eastern China: implications for their origin from suboceanic-type mantle reservoirs. Earth Planet. Sci. Lett. 105, 149-169.

Bigeleisen, J. (1965) Chemistry of isotopes. Science 147, 463-471.

Bourdon, B., Tipper, E.T., Fitoussi, C. and Stracke, A. (2010) Chondritic Mg isotope composition of the Earth. Geochim. Cosmochim. Acta 74, 5069-5083.

Brenot, A., Cloquet, C., Vigier, N., Carignan, J. and France-Lanord, C.F. (2008) Magnesium isotope systematics of the lithologically varied Moselle river basin, France. Geochim. Cosmochim. Acta 72, 5070-5089.

Brey, G.P. and Kohler, T. (1990) Geothermobarometry in four-phase lherzolites II: new thermobarometers, and practical assessment of existing thermobarometers. $J$. Petrol. 31, 1353-1378.

Brooks, C., James, D.E. and Hart, S.R. (1976) Ancient lithosphere: its role in young continental volcanism. Science 193, 1086-1094.

Chakrabarti, R. and Jacobsen, S.B. (2010) The isotopic composition of magnesium in the inner Solar System. Earth Planet. Sci. Lett. 293, 349-358.

Chakraborty, S. (2010) Diffusion coefficients in olivine, wadsleyite and ringwoodite. Rev. Mineral. Geochem. 72, 603-639. 
733 Chen, S., O'Reilly, S.Y., Zhou, X., Griffin, W.L., Zhang, G., Sun, M., Feng, J. and Zhang, M. (2001) Thermal and petrological structure of the lithosphere beneath Hannuoba, Sino-Korean Craton, China: evidence from xenoliths. Lithos 56, 267301.

Cherniak, D.J. and Dimanov, A. (2010) Diffusion in pyroxene, mica and amphibole. Rev. Mineral. Geochem. 72, 641-690.

Choi, S.H., Mukasa, S.B., Zhou, X.H., Xian, X.H. and Andronikov, A.V. (2008) Mantle dynamics beneath East Asia constrained by $\mathrm{Sr}, \mathrm{Nd}, \mathrm{Pb}$ and $\mathrm{Hf}$ isotopic systematics of ultramafic xenoliths and their host basalts from Hannuoba, North China. Chem. Geol. 248, 40-61.

Coltorti, M. (2008) Metasomatism in oceanic \& Continetnal lithospheric mantle. Geol. Soc. Spec. Pub. No. 293 (Eds. Coltorti, M. and Gregoire, M.)

Coltorti, M., Bonadiman, C., Hinton, R.W., Siena, F. and Upton, B.G.J. (1999) Carbonatite metasomatism of the oceanic upper mantle: evidence from clinopyroxenes and glasses in ultramafic xenoliths of Grande Comore, Indian Ocean. J. Petrol. 40, 133-165.

Downes, H. (2007) Origin and significance of spinel and garnet pyroxenites in the shallow lithospheric mantle: Ultramafic massifs in orogenic belts in Western Europe and NW Africa. Lithos 99, 1-24.

Fan, Q.C., Du, X.X., Sui, J.L. and Zhao, Y.W. (2010) Genesis of carbonatite from Hannuoba and Yangyuan. Acta Petrol. Sin. 26, 3189-3194 (in Chinese with English abstract).

Fan, Q.C. and Hooper, P.R. (1991) The Cenozoic basaltic rocks of eastern China: petrology and chemical composition. J. Petrol. 32, 765-810.

Fan, Q.C., Zhang, H.F., Sui, J.L., Zhai, M.G., Sun, Q. and Li, N. (2005) Magma underplating and Hannuoba present crust-mantle transitional zone composition: Xenolith petrological and geochemical evidence. Sci. China Ser. D 48, 1089-1105 (in Chinese with English abstract).

Fan, W.-M., Zhang, H.-F., Baker, J., Jarvis, K.E., Mason, P.R.D. and Menzies, M.A. (2000) On and off the North China Craton: Where is the Archaean keel? J. Petrol. 41, 933-950. 
764 Flynn, L.P., Mouginis-Mark, J. and Korton, K.A. (1994) Distribution of thermal areas on an active lava flow field: landsat observations of Kilauea, Hawaii, July 1991. Bull. Volcanol. 56, 284-296.

Foley, S.F. (2008) Ancient lithosphere: its role in young continental volcanism. Nat. Geosci. 1, 503-510.

Frey, F.A. (1980) The origin of pyroxenites and garnet pyroxenites from Salt Lake Crater, Oahu, Hawaii: trace element evidence. Am. J. Sci. 280-A, 427-449.

Frey, F.A. and Prinz, M. (1978) Ultramafic inclusions from San Carlos, Arizona: petrologic and geochemical data bearing on their petrogenesis. Earth Planet. Sci. Lett. 38, 129-176.

Galy, A., Yoffe, O., Janney, P.E., Williams, R.W., Cloquet, C., Alard, O., Halicz, L., Wadhwa, M., Hutcheon, I.D., Ramon, E. and Carignan, J. (2003) Magnesium isotope heterogeneity of the isotopic standard SRM980 and new reference materials for magnesium-isotope-ratio measurements. J. Anal. At. Spectrom. 18, 1352 - 1356.

Ganguly, J. (2010) Cation diffusion kinetics in aluminosilicate garnets and geological applications. Rev. Mineral. Geochem. 72, 559-601.

Gao, Z.-Y. and Zhang, L.-C. (1994) A study on the genesis of the mantle-derived inclusions and the host rock in Dashan volcanic cone. J. NW Univ. 24, 61-65 (in Chinese with English abstract).

Garrido, C.J. and Bodinier, J.-L. (1999) Diversity of mafic rocks in the Ronda peridotite: Evidence for pervasive melt-rock reaction during heating of subcontinental lithosphere by upwelling asthenosphere. J. Petrol. 40, 729-754.

Handler, M.R., Baker, J.A., Schiller, M., Bennett, V.C. and Yaxley, G.M. (2009) Magnesium stable isotope composition of Earth's upper mantle. Earth Planet. Sci. Lett. 282, 306-313.

Higgins, J.A. and Schrag, D.P. (2010) Constraining magnesium cycling in marine sediments using magnesium isotopes. Geochim. Cosmochim. Acta 74, 5039-5053.

Hippler, D., Buhl, D., Witbaard, R., Richter, D.K. and Immenhauser, A. (2009) Towards a better understanding of magnesium-isotope ratios from marine skeletal carbonates. Geochim. Cosmochim. Acta 73, 6134-6146. 
Huang, F., Chen, L., Wu, Z. and Wang, W. (2013) First-principles calculations of equilibrium $\mathrm{Mg}$ isotope fractionations between garnet, clinopyroxene, orthopyroxene, and olivine: implications for $\mathrm{Mg}$ isotope thermometry. Earth Planet. Sci. Lett. 367, 61-70.

Huang, J., Li, S.-G., Xiao, Y.L., Ke, S., Li, W.-Y., Tian, Y. (2015) Origin of low $\delta^{26} \mathrm{Mg}$ Cenozoic basalts from South China Block and their geodynamic implications. Geochim. Cosmochim. Acta 164 298-317.

Huang, F., Zhang, Z., Lundstrom, C.C. and Zhi, X. (2011) Iron and magnesium isotopic compositions of peridotite xenoliths from Eastern China. Geochim. Cosmochim. Acta 75, 3318-3334.

Ionov, D.A., Chanefo, I. and Bodinier, J.-L. (2005) Origin of Fe-rich lherzolites andwehrlites from Tok, SE Siberia by reactive melt percolation in refractory mantle peridotites. Contrib. Mineral. Petrol. 50, 335-353.

Irving, A.J. (1980) Petrology and geochemistry of composite ultramafic xenoliths in alkali basalts and implications for magmatic processes within the mantle. Am. J. Sci. 280, 389-426.

Kelemen, P.B., Hart, S.R. and Bernstein, S. (1998) Silica enrichment in the continental upper mantle via melt/rock reaction. Earth Planet. Sci. Lett. 164, 387-406.

Keshav, S. and Sen, G. (2004) The depth of magma fractionaiton in the oceanic mantle: Insights from garnet-bearing xenoliths from Oahu, Hawaii. Geophys. Res. Lett. 31, L04611.

Keshav, S., Sen, G. and Presnall, D.C. (2007) Garnet-bearing xenoliths from Salt Lake Crater, Oahu, Hawaii: High-pressure fractional crystallization in the oceanic mantle. J. Petrol. 48, 1681-1724.

Knoche, R., Sweeney, R.J. and Luth, R.W. (1999) Carbonation and decarbonation of eclogites: the role of garnet. Contrib. Mineral. Petrol. 135, 332-339.

Le Bas, M.J., Lemaitre, R.W., Streckeisen, A., and Zanettin, B. (1986) A chemical classification of volcanic-rocks based on the total alkali silica diagram. J. Petrol. 27, 745-750. 
824 Li, W.-Y., Teng, F.-Z., Xiao, Y.-L. and Huang, J. (2011) High-temperature inter-mineral 825 magnesium isotope fractionation in eclogite from the Dabie orogen, China. Earth Planet. Sci. Lett. 304, 224-230.

827 Liu, C.Q., Masuda, A. and Xie, G.H. (1994) Major- and trace-element compositions of 828 Cenozoic basalts in eastern China: petrogenesis and mantle source. Chem. Geol. 114, 19-42.

830 Liu, S.-A., Teng, F.-Z., He, Y., Ke, S. and Li, S.-G. (2010a) Investigation of magnesium isotope fractionation during granite differentiation: Implication for $\mathrm{Mg}$ isotopic composition of the continental crust. Earth Planet. Sci. Lett. 297, 646-654.

Liu, X.-M., Teng, F.-Z., Rudnick, R.L., McDonough, W.F. and Cummings, M.L. (2014) Massive magnesium depletion and isotope fractionation in weathered basalts. Geochim. Cosmochim. Acta 135, 336-349.

Liu, S.-A., Teng, F.-Z., Yang, W. and Wu, F.-Y. (2011) High-temperature inter-mineral magnesium isotope fractionation in mantle xenoliths from the North China craton. Earth Planet. Sci. Lett. 308, 131-140.

Liu, Y.S., Gao, S., Gao, C.G., Hu, Z.C. and Ling, W.L. (2010b) Garnet-rich granulite xenoliths from the Hannuoba basalts, north China: petrogenesis and implications for the Mesozoic crust-mantle interaction. J. Earth Sci 21, 669-691. oceanic crust recycling-induced melt-peridotite interactions in the Trans-North China Orogen: $\mathrm{U}-\mathrm{Pb}$ dating, $\mathrm{Hf}$ isotopes and trace elements in zircons from mantle xenoliths. J. Petrol. 51, 537-571.

Liu, Y.S., Gao, S., Lee, C.T.A., Hu, S.H., Liu, X.M. and Yuan, H.L. (2005) Meltperidotite interactions: Links between garnet pyroxenite and high-Mg\# signature of continental crust. Earth Planet. Sci. Lett. 234, 39-57.

853 Liu, Y.S., Yuan, H.L., Gao, S., Hu, Z.C., Wang, X., Liu, X.M. and Lin, W.L. (2004) 
the 97-158 Ma basaltic underplating and granulite-facies metamorphism. Chin. Sci. Bull. 49, 1055-1062.

857 Macris, C.A., Young, E.D. and Manning, C.E. (2013) Experimental determination of equilibrium magnesium isotope fractionation between spinel, forsterite, and magnesite from 600 to $800^{\circ} \mathrm{C}$. Geochim. Cosmochim. Acta 118, 18-32.

McDonough, W.F. (1990) Constraints on the composition of the continental lithosopheric mantle. Earth Planet. Sci. Lett. 101, 1-18.

McDonough, W.F. and Sun, S.-s. (1995) The composition of the Earth. Chem. Geol. 120, 223-253.

Nimis, P. and Taylor, W.R. (2000) Single clinopyroxene thermobarometry for garnet peridotites. Part I. Calibration and testing of a Cr-in-Cpx barometer and an enstatite-in-Cpx thermometer. Contrib. Mineral. Petrol. 139, 541-554.

Pearson, D.G., Canil, D. and Shirey, S.B. (2014) Mantle samples included in volcanic rocks: xenoliths and diamonds, in: Carlson, R.W. (Ed.), Treatise on Geochemistry. Elsevier, pp. 169-253.

Pogge von Strandmann, P.A.E. (2008) Precise magnesium isotope measurements in core top planktic and benthic foraminifera. Geochem. Geophys. Geosyst 9, Q12015, doi: 10.1029/2008GC002209.

Pogge von Strandmann, P.A.E., Elliott, T., Marschall, H.R., Coath, C., Lai, Y.J., Jeffcoate, A.B. and Ionov, D.A. (2011) Variations of Li and $\mathrm{Mg}$ isotope ratios in bulk chondrites and mantle xenoliths. Geochim. Cosmochim. Acta 75, 5247-5268.

Qian, S.P., Ren, Z.R., Zhang, L., Hong, L.B. and Liu, J.Q. (2015) Chemical and Pb isotope composition of olivine-hosted melt inclusions from the Hannuoba basalts, North China Craton: Implications for petrogenesis and mantle source. Chem. Geol. 401, 111-125.

Rapp, R.P., Shimizu, N., Norman, M.D. and Applegate, G.S. (1999) Reaction between slab-derived melts and peridotite in the mantle wedge: experimental constraints at 3.8 GPa. Chem. Geol. 160, 335-356.

Richter, F.M., Dauphas, N. and Teng, F.-Z. (2009) Non-traditional fractionation of nontraditional isotopes: evaporation, chemical diffusion and Soret diffusion. Chem. Geol. 258, 92-103. 
Rudnick, R.L., Gao, S., Ling, W.L., Liu, Y.S. and McDonough, W.F. (2004) Petrology and geochemistry of spinel peridotite xenoliths from Hannuoba and Qixia, North China Craton. Lithos 77, 609-637.

Rudnick, R.L., McDonough, F. and Chappell, B.W. (1993) Carbonatite metasomatism in the northern Tanzanian mantle: petrographic and geochemical characteristics. Earth Planet. Sci. Lett. 114, 463-475.

Saenger, C. and Wang, Z.-R. (2014) Magnesium isotope fractionation in biogenic and abiogenic carbonates: implications for paleoenvironmental proxies. Quat. Sci. Rev. 90, 1-21.

Schauble, E.A. (2011) First-principles estimates of equilibrium magnesium isotope fractionation in silicate, oxide, carbonate and hexaaquamagnesium $(2+)$ crystals. Geochim. Cosmochim. Acta 75, 844-869.

Stracke, A., Zindler, A., Salters, V.J.M., McKenzie, D., Blichert-Toft, J., Albarède, F. and Grönvold, K. (2003) Theistareykir revisited. Geochem. Geophys. Geosys. 4, doi: 10.1029/2001GC000201.

Sobolev, A.V., Hofmann, A.W., Kuzmin, D.V., Yaxley, G.M., Arndt, N.T., Chung, S.L., Danyushevsky, L.V., Elliott, T., Frey, F.A. and Garcia, M.O. (2007) The amount of recycled crust in sources of mantle-derived melts. Science 316, 412-417.

Sobolev, A.V., Hofmann, A.W., Sobolev, S.V. and Nikogosian, I.K. (2005) An olivinefree mantle source of Hawaiian shield basalts. Nature 434, 590-597.

Sobolev, N.V., Lavrent'ev, Y.G., Pokhilenko, N.P. and Usova, L.V. (1973) Chrome-rich garnets from the kimberlites of Yakutia and their parageneses. Contrib. Mineral. Petrol. 40, 39-52.

Song, Y., Frey, F.A. and Zhi, X.C. (1990) Isotopic characteristics of Hannuoba basalts, eastern China: Implications for their petrogenesis and the composition of subcontinental mantle. Chem. Geol. 88, 35-52.

Song, Y. and Frey, F.A. (1989) Geochemistry of peridotite xenoliths in basalt from Hannuoba, eastern China: Implications for subcontinental mantle heterogeneity. Geochim. Cosmochim. Acta 53, 97-113. 
915 Spera, F.J. (1984) Carbon dioxide in petrogenesis III: role of volatiles in the ascent of alkaline magma with special reference to xenolith-bearing mafic lavas. Contrib. Mineral. Petrol. 88, 217-232.

Su, B.-X., Chung, S.-L., Zarrinkoub, M.H., Pang, K.-N., Chen, L., Ji, W.-Q., Brewer, A., Ying, J.F. and Khatib, M.M. (2014) Composition and structure of the lithospheric mantle beneath NE Iran: Constraints from mantle xenoliths. Lithos 202-203, 267282.

Su, B.-X., Zhang, H.-F., Hu, Y., Santosh, M., Tang, Y.-J. and Xiao, Y. (2012a) The genesis of mantle-derived sapphirine. Am. Min. 97, 856-863.

Su, B.-X., Zhang, H.-F., Ying, J.-F., Tang, Y.-J., Hu, Y. and Santosh, M. (2012b) Metasomatized lithospheric mantle beneath the Western Qinling, Central China: Insight into carbonatite melts in the mantle. J. Geol 120, 671-681.

Tang, Y.-J., Zhang, H.-F., Nakamura, E., Moriguti, T., Kobayashi, K. and Ying, J.-F. (2007) Lithium isotopic systematics of peridotite xenoliths from Hannuoba, North China Craton: implications for melt-rock interaction in the considerably thinned lithospheric mantle. Geochim. Cosmochim. Acta 71, 4327-4341.

Tang, Y.-J., Zhang, H.-F., Ying, J.-F., Zhang, J. and Liu, X.-M. (2008) Refertilization of ancient lithospheric mantle beneath the central North China Craton: Evidence from petrology and geochemistry of peridotite xenoliths. Lithos 101, 435-452.

Tatsumoto, M., Basu, A.R., Huang, W.K., Wang, J.W. and Xie, G.H. (1992) Sr, Nd, and $\mathrm{Pb}$ isotopes of ultramafic xenoliths in volcanic-rocks of Eastern China: enriched components EMI and EMII in subcontinental lithosphere. Earth Planet. Sci. Lett. 113, 107-128.

Teng, F.-Z., Li, W.-Y., Ke, S., Yang, W., Liu, S.-A., Sedaghatpour, F., Wang, S.-J., Huang, K.-J., Hu, Y., Ling, M.-X., Xiao, Y., Liu, X.-M., Li, X.-W., Gu, H.-O., Sio, C.K., Wallace, D.A., Su, B.-X., Zhao, L., Chamberlin, J., Harrington, M. and Brewer, A. (2015) Magnesium isotopic compositions of international geostandards. Geostandard. Geoanal. Res. doi:10.1111/j.1751908X.2014.00326.x. 
944 Teng, F.-Z. and Yang, W. (2014) Comparison of factors affecting the accuracy of highprecision magnesium isotope analysis by multi-collector inductively coupled plasma mass spectrometry. Rapid Commun. Mass Spectrom. 28, 19-24.

Teng, F.-Z., Li, W.-Y., Ke, S., Marty, B., Dauphas, N., Huang, S.C., Wu, F.-Y. and

Teng, F.-Z., Wadhwa, M. and Helz, R.T. (2007) Investigation of magnesium isotope fractionation during basalt differentiation: Implications for a chondritic composition of the terrestrial mantle. Earth Planet. Sci. Lett. 261, 84-92. Pourmand, A. (2010) Magnesium isotopic composition of the Earth and chondrites. Geochim. Cosmochim. Acta 74, 4150-4166.

Tipper, E.T., Galy, A., Gaillardet, J., Bickle, M.J., Elderfield, H. and Carder, E.A. (2006b) The magnesium isotope budget of the modern ocean: Constraints from riverine magnesium isotope ratios. Earth Planet. Sci. Lett. 250, 241-253.

Tipper, E.T., Galy, A. and Bickle, M.J. (2006a) Riverine evidence for a fractionated reservoir of $\mathrm{Ca}$ and $\mathrm{Mg}$ on the continents: Implications for the oceanic $\mathrm{Ca}$ cycle. Earth Planet. Sci. Lett. 247, 267-279.

Urey, H.C. (1947) The thermodynamic properties of isotopic substances. J. Chem. Soc. (London), 562-581.

von Seckendorff, V. and O'Neill, H.S.C. (1993) An experimental study of Fe-Mg partitioning between olivine and orthopyroxene at 1173, 1273 and $1423 \mathrm{~K}$ and 1.6 GPa. Contrib. Mineral. Petrol. 113, 196-207.

Walter, M.J. (1998) Melting of garnet peridotite and the origin of komatiite and depleted lithosphere. J. Petrol. 39, 29-60.

Walter, M.J. (2003) Melt extraction and compositional variability in mantle lithosphere, in: Carlson, R.W. (Ed.), Treatise on Geochemistry-The mantle and core. Carnegie Institute of Washington, Washington D.C., pp. 363-394.

Wang, C., Jin, Z.-M., Gao, S., Zhang, J.-F. and Zheng, S. (2010) Eclogite-melt/peridotite reaction: experimental constraints on the destruction mechanism of the North China Craton. Science China Earth Sciences 53, 797-809.

Wang, F.-Z., Jin, L.-Y., Xu, Y.-R., 1987. The study of ultramafic inclusions in Cenozoic basalt in Shandong, Linqu of Shandong. Earth Sci. 12, 249-256 (in Chinese with English abstract). 
975 Wang, S.-J., Teng, F.-Z. and Li, S.-G. (2014a) Tracing carbonate-silicate interaction during subduction using magnesium and oxygen isotopes. Nat. commun. 5, doi: $10.1038 /$ ncomms6328.

978 Wang, S.-J., Teng, F.-Z., Li, S.-G. and Hong, J.-A. (2014b) Magnesium isotopic systematics of mafic rocks during continental subduction. Geochim. Cosmochim. Acta 143, 34-48.

Wang, S.-J., Teng, F.-Z., Williams, H.M. and Li, S.-G. (2012) Magnesium isotopic variations in cratonic eclogites: origins and implications. Earth Planet. Sci. Lett. 359-360, 219-226.

Wilshire, H.G. and Shervais, J.W. (1975) Al-augite and Cr-diopside ultramafic xenoliths in basaltic rocks from western United States. Phys. Chem. Earth 9, 257-272.

Wombacher, F., Eisenhauer, A., Böhm, F., Gussone, N., Regenberg, M., Dullo, W.-C. and Rüggeberg, A. (2011) Magnesium stable isotope fractionation in marine biogenic calcite and aragonite. Geochim. Cosmochim. Acta 75, 5797-5818.

Xiao, Y., Teng, F.-Z., Zhang, H.-F. and Yang, W. (2013) Large magnesium isotope

994 Xu, X.-S., O'Reilly, S.Y., Griffin, W.L., Zhou, X.-M. and Huang, X.-L. (1998) The nature of the Cenozoic lithosphere at Nüshan, Eastern ChinaFlower, M.F.J., in: fractionation in peridotite xenoliths from eastern North China craton: Product of melt-rock interaction. Geochim. Cosmochim. Acta 115, 241-261. Chung, S.L., Lo, C.H., Lee, T.Y. (Eds.), Mantle dynamics and plate interactions in East Asia. American Geophysical Union, pp. 167-196.

Yan, J., Chen, J.-F., Xie, Z. and Zhou, T.-X. (2003) Mantle derived xenoliths in the late 1002 Cretaceous basalts in eastern Shandong: New constraints on the timing of lithospheric thinning in east China. Chin. Sci. Bull. 48, 1570-1574 (in Chinese with English abstract). 
1005 Yang, W., Teng, F.-Z., Zhang, H.-F. and Li, S.-G. (2012) Magnesium isotopic 1006 systematics of continental basalts from the North China craton: Implications for tracing subducted carbonate in the mantle. Chem. Geol. 328, 185-194.

1008 Yang, W., Teng, F.-Z. and Zhang, H.-F. (2009) Chondritic magnesium isotopic composition of the terrestrial mantle: A case study of peridotite xenoliths from the North China craton. Earth Planet. Sci. Lett. 288, 475-482.

Yaxley, G.M., Crawford, A.J. and Green, D.H. (1991) Evidence for carbonatite metasomatism in spinel peridotite xenoliths from western Victoria, Australia. Earth Planet. Sci. Lett. 107, 305-317.

Yaxley, G.M. (2000) Experimental study of the phase and melting relations of homogeneous basalt + peridotite mixtures and implications for the petrogenesis of flood basalts. Contrib. Mineral. Petrol. 139, 326-338.

Ying, J.-F., Zhang, H.-F., Tang, Y.-J., Su, B.-X. and Zhou, X.-H. (2013) Diverse crustal components in pyroxenite xenoliths from Junan, Sulu orogenic belt: Implications for lithospheric modification invoked by continental subduction. Chem. Geol. 356, 181-192.

Ying, J.-F., Zhou, X.-H. and Zhang, H.-F. (2004) Geochemical and isotopic investigation of the Laiwu-Zibo carbonatites from western Shandong Province, China, and implications for their petrogenesis and enriched mantle source. Lithos 75, 413-426.

1030 Young, E.D., Manning, C.E., Schauble, E.A., Shahar, A. Macris, C.A., Lazar, C. and Jordan, M. (2015) High-temperature equilibrium isotope fractionation of non1033 traditional stable isotopes: experiments, theory, and applications. Chem. Geol. 395, 176-195. 
1034 Young, E.D., Tonui, E., Manning, C.E., Schauble, E. and Macris, C.A. (2009) Spinelolivine magnesium isotope thermometry in the mantle and implications for the Mg isotopic composition of Earth. Earth Planet. Sci. Lett. 288, 524-533.

Yu, C.-M., Zheng, J.-P. and Griffin, W.L. (2006) Petrography and geochemistry of peridotite xenoliths from Hannuoba and significance for lithospheric mantle evolution. J. China Univ. Geosci. 17, 25-33 (in Chinese with English abstract).

Yu, S.-Y., Xu, Y.-G., Ma, J.-L., Zheng, Y.-F., Kuang, Y.-S., Hong, L.-B., Ge, W.-C. and Tong, L.-X. (2010) Remnants of oceanic lower crust in the subcontinental lithospheric mantle: trace element and $\mathrm{Sr}-\mathrm{Nd}-\mathrm{O}$ isotope evidence from aluminous garnet pyroxenite xenoliths from Jiaohe, Northeast China. Earth Planet. Sci. Lett.297, 413-422.

Zhang, H.-F., Deloule, E., Tang, Y.-J. and Ying, J.-F. (2010a) Melt/rock interaction in remains of refertilized Archean lithospheric mantle in Jiaodong Peninsula, North China Craton: Li isotopic evidence. Contrib. Mineral. Petrol. 160, 261-277.

Zhang, H.-F., Nakamura, E., Kobayashi, K., Zhang, J., Ying, J.-F., Tang, Y.-J.and Niu, L.-F. (2007a) Transformation of subcontinental lithospheric mantle through deformation-enhanced peridotite-melt reaction: evidence from a highly fertile mantle xenolith from the North China craton. Int. Geol. Rev. 49, 658-679.

Zhang, H.-F., Ying, J.-F., Shimoda, G., Kita, N.T., Morishita, Y., Shao, J.-A. and Tang, Y.-J. (2007b) Importance of melt circulation and crust-mantle interaction in the lithospheric evolution beneath the North China Craton: Evidence from Mesozoic basalt-borne clinopyroxene xenocrysts and pyroxenite xenoliths. Lithos 96, 67-89.

Zhang, H.-F. (2009) Peridotite-melt interaction: a key point for the destruction of cratonic lithospheric mantle. Chin. Sci. Bull. 54, 3417-3437.

Zhang, S.-H., Zhao, Y., Song, B., Hu, J.-M., Liu, S.-W., Yang, Y.-H., Chen, F.-K., Liu, X.-M. and Liu, J. (2009) Contrasting Late Carboniferous and Late PermianMiddle Triassic intrusive suites from the northern margin of the North China craton: geochronology, petrogenesis, and tectonic implications. Geol. Sco. Am. Bull. 121, 181-200.

Zhang, J.-F., Wang, C. and Wang, Y.F. (2012) Experimental constraints on the destruction mechanism of the North China Craton. Lithos 149, 91-99. 
1065 Zhang, Y., Ni, H. and Chen, Y. (2010b) Diffusion data in silicate melts. Rev. Mineral. 1066 Geochem. 72, 311-408.

1067 Zhao, X.-M., Zhang, H.-F., Zhu, X.-K., Tang, S. and Tang, Y. (2010) Iron isotope 1068 variations in spinel peridotite xenoliths from North China Craton: implications for mantle metasomatism. Contrib. Mineral. Petrol. 160, 1-14.

1070 Zheng, J.P., Griffin, W.L., Qi, L., O'Reilly, S.Y., Sun, M., Zheng, S., Pearson, N., Gao, 1071 J.F., Yu, C.M., Su, Y.P., Tang, H.Y., Liu, Q.S. and Wu, X.L. (2009) Age and composition of granulite and pyroxenite xenoliths in Hannuoba basalts reflect

Zheng, J.P., O'Reilly, S.Y., Griffin, W.L., Lu, F.-X. and Zhang, M. (1998) Nature and 1076 evolution of Cenozoic lithospheric mantle beneath Shandong peninsula, SinoKorean Craton, eastern China. Int. Geol. Rev. 40, 471-499.

1078 Zhi, X.-C., Song, Y., Frey, F.A., Feng, J.-L. and Zhai, M.-Z. (1990) Geochemistry of Hannuoba basalts, eastern China: constraints on the origin of continental alkali and tholeiitic basalt. Chem. Geol. 88, 1-33.

1081 Zhu, B.Q. (1998) Theory and applications of isotope systematics in geosciences: Evolution of continental crust and mantle in China (in Chinese). Science Press, Beijing. 


\section{Figure captions}

1086 Fig. 1. Petrological and petrographic characteristics of garnet-bearing xenoliths. (A): A 1087 hand specimen of garnet websterite with garnet-rich veins. (B): A scanned thin section 1088 image of a garnet websterite showing the typical mineral assemblage of Ol-Cpx-Opx-Grt1089 Spl. (C): A photomicrograph of a typical spinel-cored garnet. (D) - (G): 1090 Photomicrographs showing gradual replacement of spinel by garnet. $(\mathrm{H})$ - $(\mathrm{J})$ : A 1091 photomicrograph showing garnet engulfs and consumes pyroxene and olivine grains. (K) 1092 A photomicrograph showing the triple junction and kink bands in Opx. (L) A 1093 photomicrograph showing the fluid/melt inclusions in pyroxene. (M) A Back-scattered 1094 electron (BSE) image showing texturally equilibrated but compositionally zoned olivine 1095 grains. (N) A BSE image showing the rare metasomatic Ap and Phl in a glass vein. (O) 1096 and (P) BSE images showing a glass vein in the xenolith, with chemically zoned olivine. 1097 (P) is a close-up of $(\mathrm{O})$ to show the intergrowth texture of kelyphitic garnet. All the 1098 garnets in our sample collection have been decomposed to kelyphites. $\mathrm{Ol}=$ olivine; $\mathrm{Cpx}$ 1099 = clinopyroxene; Opx = orthopyroxene; Grt = garnet; $\mathrm{Spl}=$ spinel; $\mathrm{Ap}=$ apatite; $\mathrm{Phl}=$ 1100 phlpgopite; Gls = glass; $\mathrm{Pl}=$ plagioclase .

1102 Fig. 2. Major (A-C) and trace (D) element variations of Hannuoba mantle xenoliths 1103 studied here in relation to their $\mathrm{MgO}$ (wt.\%). Data for Hannuoba peridotites (Song and 1104 Frey, 1989; Chen et al., 2001; Rudnick et al., 2004; Fan et al., 2005; Choi et al., 2008) 1105 and Beiyan wehrlites (Xiao and Zhang, 2011; Xiao et al., 2013) are plotted for 1106 comparison. The star denotes the composition of primitive mantle from McDonough and 1107 Sun (1995). The dash grey lines represent the compositional fields of typical cratonic 1108 peridotites defined by Tanzanian xenoliths (Lee and Rudnick, 1999). The orange solid 1109 lines represent extension between the residual Hannuoba peridotites and calculated 1110 equilibrium melts taken from $\mathrm{Xu}$ (2002). The data for Jiaohe oceanic crustal pyroxenites 1111 field are from Yu et al. (2010). The data for Hannuoba basalts are from Zhi et al. (1990), 1112 Basu et al. (1991), Fan et al. (1991), Liu et al. (1994), Qian et al. (2015) and this study 1113 (open square). The fields of MORB in (A) and (B) are from Downes (2007) with data 1114 from Melson et al. (1976), Schilling et al. (1983), Korenaga and Kelemen (2000), in (C) 
1115 is from Bodinier and Godard (2014) with data from the PetDB database, and in (D) is

1116 from Yu et al. (2010) with data from Jacob (2004). Major element data are from Table S2.

1117 Mineral compositional data for Ol, Cpx, Opx, Grt in (C) are from Table S4-8. Lherz =

1118 Lherzolite, Webst $=$ Websterite, Cpxnt $=$ Clinopyroxenite, Opxnt $=$ Orthopyroxenite

1120 Fig. 3. Trace element features for Hannuoba mantle xenoliths. (A) and (C) are chondrite1121 normalized REE patterns for garnet-bearing and garnet-free xenoliths, respectively; (B)

1122 and (D) are primitive mantle-normalized trace element patterns for garnet-bearing and 1123 garnet-free xenoliths, respectively. Chondrite values are from Anders and Grevesse 1124 (1989); Primitive mantle and N-MORB values are from McDonough and Sun (1995).

1125 Light blue fields represent data of Hannuoba spinel lherzolites from Rudnick et al. (2004) 1126 and Song and Frey (1990). Trace element data are from Table S3.

1128 Fig. 4. Mineral chemical composition plots for Hannuoba mantle xenoliths. (A) Mg\# vs. $1129 \mathrm{NiO}$ wt.\% in olivine. (B) $\mathrm{Mg} \#$ vs. $\mathrm{Al}_{2} \mathrm{O}_{3}$ wt.\% in clinopyroxene. (C) $\mathrm{Mg} \#$ vs. $\mathrm{Cr} \#$ in 1130 spinel. In (A) and (B), fields of cratonic and non-cratonic mantle peridotites, and 1131 pyroxenite cumulates worldwide are from Walter (2003). Data for mantle peridotitic 1132 xenoliths from the Tanlu Fault Zone regions are from Fan et al. (2000), Gao and Zhang 1133 (1994), Rudnick et al. (2004), Wang et al. (1987), Xu et al. (1998), Yan et al. (2003), 1134 Zhang et al. (2007b), and Zheng et al. (1998). Metasomatism trend in (B) is from Su et al. 1135 (2014). Data for spinels from the peridotite-basalt reaction zone are from Zhang (2007a). 1136 (A) - (C) are modified from Zhang et al (2007a). (D) Garnet composition in terms of $\mathrm{CaO}$ 1137 wt.\% vs. $\mathrm{Cr}_{2} \mathrm{O}_{3}$ wt.\%, modified after Sobolev et al. (1973). Mineral chemical data are 1138 from Tables S4-8.

1140 Fig. 5. Wo-En-Fs classification quadrilateral of pyroxenes from Hannuoba mantle 1141 xenoliths.

1143 Fig. 6. $\mathrm{Mg} \#$ correlations between co-existing $\mathrm{Cpx}-\mathrm{Ol}$ (A) and $\mathrm{Opx}-\mathrm{Ol}$ (B). $\mathrm{Mg} \#=100 \times$ 1144 molar $\mathrm{Mg} /(\mathrm{Mg}+\mathrm{Fe})$. The best-fit lines are obtained by setting the intercepts to zero. Data 1145 are from Table S6-8. 
1147 Fig. 7. Compilation of $\delta^{26} \mathrm{Mg}$ (\%) for mantle-related rocks (A) and mineral separates (B).

1148 Mantle range is defined as $\delta^{26} \mathrm{Mg}=-0.25 \pm 0.07 \%$ (Teng et al., 2010). Global seawater

1149 range is defined as $\delta^{26} \mathrm{Mg}=-0.83 \pm 0.09 \%$ (Ling et al., 2011). Data for Hannuoba mantle

1150 xenoliths are from Table 4 and 6. Literature data are shown as grey open symbols while

1151 colorful symbols are data from this study. Data sources: Spl: Young et al. (2009), Liu et

1152 al. (2011), Xiao et al. (2013); Ol, Cpx and Opx: Young et al. (2009), Handler et al. (2009),

1153 Yang et al. (2009), Liu et al. (2011), Huang et al. (2011), Xiao et al. (2013); Cratonic

1154 eclogite, eclogitic Cpx and Grt: Wang et al. (2012); Pyroxenite: Liu et al. (2011);

1155 Oceanic basalts: Bourdon et al. (2010), Teng et al. (2010); Continental basalts: Yang et al.

1156 (2012), Huang et al. (2015); Peridotites: Young et al. (2009), Yang et al. (2009), Bourdon

1157 et al. (2010), Teng et al. (2010), Huang et al. (2011), Liu et al. (2011), Pogge von

1158 Strandmann et al. (2011), Xiao et al. (2013); Wehrlites: Yang et al. (2009), Teng et al.

1159 (2010), Pogge von Strandmann et al. (2011), Xiao et al. (2013).

1161 Fig. 8. $\delta^{26} \mathrm{Mg}(\%)$ of the Hannuoba garnet-bearing xenoliths in relation to their $\mathrm{MgO}$

1162 (wt.\%). The two grey lines represent mixing lines between peridotites from the North

1163 China Craton (Teng et al. 2010) and cratonic eclogites from South African (Wang et al.,

1164 2012). End-member compositions: The lightest eclogites has a $\delta^{26} \mathrm{Mg}$ value of $-0.798 \%$

1165 and $\mathrm{MgO}$ content of 7.37 wt.\%., while the heaviest eclogite has a $\delta^{26} \mathrm{Mg}$ value of $-0.139 \%$ o

1166 and $\mathrm{MgO}$ content of 17.05 wt. $\%$. The $\delta^{26} \mathrm{Mg}$ values for NCC peridotites range from $-0.27 \%$ o

1167 to $-0.21 \%$.

1168

1169 Fig. 9. Ti/Eu vs. $(\mathrm{La} / \mathrm{Yb})_{\mathrm{N}}$ plot for distinguishing between carbonatite metasomatism and

1170 silicate metasomatism (Coltorti et al., 1999).

1172 Fig. 10. (A) and (B): Correlations of inter-mineral fractionation between Cpx-Ol and 1173 Opx-Ol with $10^{6} / \mathrm{T}^{2}$ ( $\mathrm{T}$ in $\mathrm{K}$ ). $\Delta^{26} \mathrm{Mg}_{\mathrm{X}-\mathrm{Y}}=\delta^{26} \mathrm{Mg}_{\mathrm{X}}-\delta^{26} \mathrm{Mg}_{\mathrm{Y}}$, where $\mathrm{X}$ and $\mathrm{Y}$ represent 1174 different mineral phases. The theoretically calculated lines of Schauble (2011) [black 1175 solid lines], and Cpx-Ol equilibrium fractionation line established by natural samples 1176 (Liu et al., 2011) [dashed line] are plotted for comparison. Data are from Table 4. (C) 
1177 Variation of $10^{3} \ln \alpha_{\text {Cpx-Grt }}$ with $10^{6} / \mathrm{T}^{2}$ ( $\mathrm{T}$ in $\mathrm{K}$ ) based on density functional theory 1178 calculation in Huang et al. (2013). Theoretical equilibrium fractionation lines between 1179 co-existing garnet and clinopyroxene at $0 \mathrm{GPa}$ (green solid line) and $2 \mathrm{GPa}$ (blue solid 1180 line), and that established by empirical measurements on equilibrated eclogitic Grt-Cpx 1181 pairs (orange dash line) are shown for reference. (D) and (E) Correlation of $\delta^{26} \mathrm{Mg}_{\text {Grt }}$ vs. $1182 \delta^{26} \mathrm{Mg}_{\mathrm{Cpx}}$ and $\delta^{26} \mathrm{Mg}_{\mathrm{OI}}$ vs. $\delta^{26} \mathrm{Mg}_{\mathrm{Grt}}$ at different equilibrium temperatures. (F) Negative 1183 correlation between $\delta^{26} \mathrm{Mg}$ of Grt and $\mathrm{MgO}$ content of Spl. The calculated equilibrium $1184 \mathrm{Mg}$ isotope fractionation lines are from Huang et al. (2013) by assuming the equilibrium 1185 pressure of 1.5 GPa throughout. Data for cratonic eclogites (Wang et al., 2012) and 1186 orogenic eclogites ( $\mathrm{Li}$ et al., 2011; Wang et al., 2014b) are shown for comparison, with 1187 estimated peak metamorphic pressure of $5 \mathrm{GPa}$ and $3 \mathrm{GPa}$, respectively. Data are from 1188 Tables 4 and 5.

1190 Fig. 11. (A) $\delta^{26} \mathrm{Mg}$ (\%) versus $\mathrm{Ti} / \mathrm{Eu}$ ratio for the two Hannuoba garnet-free 1191 clinopyroxenites can be modeled by binary mixing between peridotites from the North 1192 China Craton (Teng et al. 2010) and carbonatites that have $\delta^{26} \mathrm{Mg}$ of -3.00 to $-5.00 \%$. $1193 \mathrm{Ti} / \mathrm{Eu}$ ratios of the carbonatites are based on the average composition of Hannuoba 1194 carbonatites reported by Fan et al. (2010). Error bars for $\delta^{26} \mathrm{Mg}$ are smaller than the 1195 sample symbols. (B) Calculated equilibrated melts with these clinopyroxenites by using 1196 the Cpx-carbonatite partition coefficients provided in Adam and Green (2001). 1197 Compositions of carbonatites from the North China Craton (Ying et al., 2004) and 1198 Hannuoba basalts (Qian et al., 2015) are shown for comparison. 
Table 1

Magnesium isotopic compositions (\%) of standards analyzed during the course of this study, and comparison with literature data

\begin{tabular}{|c|c|c|c|c|c|c|c|c|c|c|c|c|c|}
\hline Standard & Description & $\mathrm{n}$ & $\delta^{26} \mathrm{Mg}$ & $2 \mathrm{SD}$ & $\delta^{25} \mathrm{Mg}$ & $2 \mathrm{SD}$ & Standard & Description & $\mathrm{n}$ & $\delta^{26} \mathrm{Mg}$ & 2SD & $\delta^{25} \mathrm{Mg}$ & $2 \mathrm{SD}$ \\
\hline \multirow{13}{*}{$\begin{array}{l}\text { Hawaii } \\
\text { Seawater } \\
\text { (in-house) }\end{array}$} & $\mathrm{HI}$ & & -0.92 & 0.07 & -0.48 & 0.05 & \multirow{4}{*}{$\begin{array}{l}\text { KH Olivine } \\
\text { (in-house) }\end{array}$} & \multirow[t]{4}{*}{ Kilbourne Hole, NM } & & -0.29 & 0.07 & -0.18 & 0.06 \\
\hline & & & -0.84 & 0.07 & -0.45 & 0.05 & & & & -0.30 & 0.08 & -0.15 & 0.07 \\
\hline & & & -0.89 & 0.07 & -0.48 & 0.06 & & & & -0.29 & 0.07 & -0.13 & 0.05 \\
\hline & & & -0.79 & 0.06 & -0.40 & 0.06 & & & & -0.22 & 0.07 & -0.13 & 0.04 \\
\hline & & & -0.82 & 0.06 & -0.41 & 0.05 & \multirow[t]{3}{*}{ Average } & This study & 16 & -0.27 & 0.05 & -0.14 & 0.05 \\
\hline & & & -0.83 & 0.06 & -0.43 & 0.05 & & Teng et al. (2010) & 16 & -0.27 & 0.07 & -0.14 & 0.04 \\
\hline & & & -0.83 & 0.06 & -0.40 & 0.04 & & Teng et al. (2007) & 24 & -0.31 & 0.09 & -0.14 & 0.08 \\
\hline & & & -0.85 & 0.07 & -0.44 & 0.07 & \multirow{2}{*}{ DTS-1 (USGS) } & \multirow{2}{*}{\multicolumn{2}{|c|}{$\begin{array}{l}\text { Dunite, Twin Sisters } \\
\text { mountain, WA }\end{array}$}} & -0.31 & 0.08 & -0.14 & 0.07 \\
\hline & & & -0.83 & 0.08 & -0.42 & 0.07 & & & & -0.30 & 0.06 & -0.15 & 0.06 \\
\hline & & & -0.87 & 0.07 & -0.44 & 0.07 & Average & \multirow[t]{2}{*}{ This study } & \multirow[t]{4}{*}{2} & -0.30 & 0.05 & -0.14 & 0.04 \\
\hline & & & -0.82 & 0.07 & -0.44 & 0.05 & \multirow{2}{*}{$\begin{array}{l}\text { Recommended } \\
\text { PCC-1 (USGS) }\end{array}$} & & & -0.302 & 0.027 & -0.132 & 0.031 \\
\hline & & & -0.84 & 0.07 & -0.44 & 0.05 & & \multirow[t]{2}{*}{ Peridotite, Cazadero, CA } & & -0.20 & 0.07 & -0.10 & 0.05 \\
\hline & & & -0.84 & 0.06 & -0.43 & 0.06 & Recommended & & & -0.229 & 0.041 & -0.101 & 0.028 \\
\hline \multirow[t]{6}{*}{ Average } & This study & 13 & -0.84 & 0.07 & -0.43 & 0.05 & BHVO & \multirow{2}{*}{$\begin{array}{l}\text { Basalt, Hawaiian Volcanic } \\
\text { Observatory }\end{array}$} & & -0.22 & 0.06 & -0.14 & 0.05 \\
\hline & Ling et al. (2011) & 90 & -0.83 & 0.09 & -0.43 & 0.06 & (USGS) & & & -0.20 & 0.07 & -0.08 & 0.03 \\
\hline & Higgins \& Schrag (2010) & 20 & -0.79 & 0.18 & - & - & Average & \multirow[t]{2}{*}{ This study } & 2 & -0.21 & 0.05 & -0.10 & 0.38 \\
\hline & Foster et al. (2010) & 26 & -0.82 & 0.06 & -0.43 & 0.04 & Recommended & & & -0.207 & 0.039 & -0.123 & 0.027 \\
\hline & Hippler et al. (2009) & 10 & -0.80 & 0.05 & -0.42 & 0.02 & W-1 (USGS) & \multirow[t]{2}{*}{ Diabase, Centreville, VA } & & -0.15 & 0.06 & -0.08 & 0.05 \\
\hline & Bolou-Bi et al. (2012) & 14 & -0.89 & 0.10 & -0.47 & 0.08 & Recommended & & & -0.164 & 0.030 & -0.079 & 0.024 \\
\hline \multirow[t]{12}{*}{$\begin{array}{l}\text { KH Olivine } \\
\text { (in-house) }\end{array}$} & Kilbourne Hole, NM & & -0.25 & 0.08 & -0.13 & 0.06 & $\begin{array}{l}\text { MAG-1 } \\
\text { (USGS) }\end{array}$ & \multirow[t]{2}{*}{ Marine mud, Gulf of Maine } & & -0.24 & 0.06 & -0.07 & 0.06 \\
\hline & & & -0.26 & 0.06 & -0.13 & 0.04 & Recommended & & & -0.252 & 0.045 & -0.113 & 0.036 \\
\hline & & & -0.26 & 0.05 & -0.17 & 0.05 & \multirow{2}{*}{$\begin{array}{l}\text { Murchison } \\
\text { chondrite }\end{array}$} & \multirow{2}{*}{$\begin{array}{l}\text { Carbonaceous (CM2), VIC, } \\
\text { Australia }\end{array}$} & & -0.29 & 0.06 & -0.14 & 0.06 \\
\hline & & & -0.25 & 0.06 & -0.11 & 0.05 & & & & -0.28 & 0.07 & -0.15 & 0.05 \\
\hline & & & -0.23 & 0.07 & -0.15 & 0.05 & \multirow[t]{8}{*}{ Average } & This study & 2 & -0.29 & 0.04 & -0.15 & 0.04 \\
\hline & & & -0.27 & 0.06 & -0.15 & 0.06 & & $\begin{array}{l}\text { Pogge von Strandmann et al. } \\
\text { (2011) }\end{array}$ & 1 & -0.23 & 0.02 & -0.13 & 0.01 \\
\hline & & & -0.28 & 0.06 & -0.14 & 0.06 & & Teng et al. (2010) & 4 & -0.31 & 0.07 & -0.17 & 0.03 \\
\hline & & & -0.25 & 0.08 & -0.09 & 0.07 & & Teng et al. (2007) & 4 & -0.41 & 0.05 & -0.21 & 0.05 \\
\hline & & & -0.25 & 0.05 & -0.10 & 0.04 & & Yang et al. (2009) & 4 & -0.31 & 0.06 & -0.17 & 0.06 \\
\hline & & & -0.25 & 0.05 & -0.13 & 0.04 & & Wiechert \& Halliday (2007) & 13 & -0.26 & 0.25 & -0.14 & 0.14 \\
\hline & & & -0.29 & 0.07 & -0.12 & 0.06 & & Wombacher et al. (2009) & 17 & -0.26 & 0.09 & -0.13 & 0.07 \\
\hline & & & -0.29 & 0.06 & -0.14 & 0.05 & & Bourdon et al. (2010) & 2 & -0.19 & 0.08 & -0.11 & 0.02 \\
\hline
\end{tabular}

$\mathrm{n}$ indicates number of analyses. Recommended values are from Teng et al. (2015). 
Table 2

Reproducibility check of Mg isotopic measurements (\%o) relative to standard DSM3

\begin{tabular}{|c|c|c|c|c|c|c|c|c|c|}
\hline \multirow[t]{2}{*}{ Sample } & \multicolumn{4}{|c|}{ Ol } & \multirow[t]{2}{*}{ Sample } & \multicolumn{4}{|c|}{ Cpx } \\
\hline & $\delta^{26} \mathrm{Mg}$ & 2SD & $\delta^{25} \mathrm{Mg}$ & $2 \mathrm{SD}$ & & $\delta^{26} \mathrm{Mg}$ & 2SD & $\delta^{25} \mathrm{Mg}$ & $2 \mathrm{SD}$ \\
\hline D 01 & 0.06 & 0.06 & 0.04 & 0.04 & D 06 & 0.02 & 0.05 & -0.01 & 0.04 \\
\hline D $01 \mathrm{rc}$ & 0.04 & 0.07 & 0.02 & 0.07 & D 06 rc & 0.00 & 0.07 & 0.00 & 0.06 \\
\hline Average & 0.05 & 0.05 & 0.03 & 0.03 & Average & 0.02 & 0.04 & -0.01 & 0.03 \\
\hline D 06 & -0.03 & 0.08 & -0.02 & 0.06 & D 07 & -0.12 & 0.05 & -0.07 & 0.04 \\
\hline D 06 rd & 0.01 & 0.06 & 0.01 & 0.04 & D $07 \mathrm{rc}$ & -0.09 & 0.07 & -0.06 & 0.06 \\
\hline Average & 0.00 & 0.05 & 0.00 & 0.03 & Average & -0.11 & 0.04 & -0.06 & 0.03 \\
\hline D 09 & -0.01 & 0.07 & 0.00 & 0.05 & D 09 & -0.11 & 0.05 & -0.06 & 0.04 \\
\hline D 09 rd & 0.01 & 0.06 & 0.04 & 0.04 & D 09 rd & -0.12 & 0.07 & -0.08 & 0.06 \\
\hline Average & 0.00 & 0.05 & 0.03 & 0.03 & Average & -0.11 & 0.04 & -0.07 & 0.03 \\
\hline D 22 & -0.29 & 0.07 & -0.14 & 0.07 & D 7S & -0.45 & 0.05 & -0.20 & 0.04 \\
\hline D $22 \mathrm{rr}$ & -0.28 & 0.06 & -0.13 & 0.06 & D 7S rc & -0.47 & 0.07 & -0.24 & 0.06 \\
\hline D $22 \mathrm{rc}$ & -0.26 & 0.07 & -0.14 & 0.03 & Average & -0.46 & 0.04 & -0.21 & 0.03 \\
\hline Average & -0.28 & 0.04 & -0.13 & 0.03 & D $2 S$ & -0.11 & 0.07 & -0.08 & 0.06 \\
\hline D 7S & -0.39 & 0.06 & -0.19 & 0.04 & $\mathrm{D} 2 \mathrm{~S} \mathrm{rr}$ & -0.11 & 0.06 & -0.05 & 0.06 \\
\hline D 7S rc & -0.41 & 0.07 & -0.23 & 0.07 & D $2 \mathrm{~S} \mathrm{rc} 1$ & -0.14 & 0.06 & -0.07 & 0.06 \\
\hline Average & -0.40 & 0.05 & -0.20 & 0.03 & D $2 \mathrm{~S} \mathrm{rc} 2$ & -0.11 & 0.07 & -0.04 & 0.03 \\
\hline D $2 \mathrm{~S}$ & -0.12 & 0.07 & -0.08 & 0.05 & Average & -0.12 & 0.03 & -0.05 & 0.02 \\
\hline D $2 \mathrm{~S} \mathrm{rc}$ & -0.16 & 0.07 & -0.09 & 0.07 & & & & & \\
\hline Average & -0.14 & 0.05 & -0.08 & 0.04 & & & & & \\
\hline \multirow[t]{2}{*}{ Sample } & \multicolumn{4}{|c|}{ Grt } & Sample & \multicolumn{4}{|c|}{ Opx } \\
\hline & $\delta^{26} \mathrm{Mg}$ & $2 \mathrm{SD}$ & $\delta^{25} \mathrm{Mg}$ & 2SD & & $\delta^{26} \mathrm{Mg}$ & $2 \mathrm{SD}$ & $\delta^{25} \mathrm{Mg}$ & $2 \mathrm{SD}$ \\
\hline D $6 \mathrm{~S}$ & -0.53 & 0.05 & -0.23 & 0.05 & D 06 & -0.02 & 0.06 & 0.01 & 0.05 \\
\hline D $6 \mathrm{~S} \mathrm{rr}$ & -0.53 & 0.07 & -0.28 & 0.03 & $\mathrm{D} 06 \mathrm{rc}$ & 0.01 & 0.07 & 0.00 & 0.06 \\
\hline D $6 \mathrm{~S} \mathrm{rc}$ & -0.49 & 0.07 & -0.27 & 0.03 & Average & -0.01 & 0.05 & 0.00 & 0.04 \\
\hline Average & -0.52 & 0.03 & -0.27 & 0.02 & D 07 & -0.09 & 0.06 & -0.04 & 0.05 \\
\hline D 01 & -0.74 & 0.07 & -0.38 & 0.05 & D $07 \mathrm{rc}$ & -0.10 & 0.07 & -0.04 & 0.05 \\
\hline D $01 \mathrm{rr}$ & -0.76 & 0.08 & -0.40 & 0.06 & Average & -0.10 & 0.05 & -0.04 & 0.03 \\
\hline Average & -0.75 & 0.05 & -0.39 & 0.04 & D 09 & 0.00 & 0.06 & 0.04 & 0.04 \\
\hline D 06 & -0.39 & 0.08 & -0.18 & 0.07 & D 09 rd & 0.00 & 0.07 & 0.00 & 0.05 \\
\hline D $06 r r$ & -0.38 & 0.06 & -0.19 & 0.06 & Average & 0.00 & 0.04 & 0.02 & 0.03 \\
\hline D 06 rc1 & -0.36 & 0.06 & -0.20 & 0.05 & D 7S & -0.37 & 0.06 & -0.17 & 0.05 \\
\hline D $06 \mathrm{rc} 1 \mathrm{rr}$ & -0.34 & 0.06 & -0.18 & 0.06 & D 7S rc & -0.38 & 0.07 & -0.19 & 0.05 \\
\hline D 06 rc2 & -0.37 & 0.06 & -0.20 & 0.06 & Average & -0.37 & 0.05 & -0.18 & 0.03 \\
\hline Average & -0.37 & 0.03 & -0.19 & 0.03 & & & & & \\
\hline D 07 & -0.47 & 0.05 & -0.27 & 0.05 & & & & & \\
\hline D $07 \mathrm{rc}$ & -0.51 & 0.06 & -0.25 & 0.05 & & & & & \\
\hline Average & -0.48 & 0.04 & -0.26 & 0.04 & Sample & & Whol & & \\
\hline $\mathrm{D} 4 \mathrm{~S}$ & -0.48 & 0.08 & -0.22 & 0.07 & & $\delta^{26} \mathrm{Mg}$ & $2 \mathrm{SD}$ & $\delta^{25} \mathrm{Mg}$ & $2 \mathrm{SD}$ \\
\hline $\mathrm{D} 4 \mathrm{~S} \mathrm{rc}$ & -0.50 & 0.07 & -0.26 & 0.07 & D 06 & -0.10 & 0.07 & -0.05 & 0.05 \\
\hline D $4 \mathrm{~S}$ rcrr & -0.45 & 0.07 & -0.23 & 0.05 & $\mathrm{D} 06 \mathrm{rc}$ & -0.10 & 0.07 & -0.05 & 0.05 \\
\hline Average & -0.47 & 0.04 & -0.23 & 0.04 & Average & -0.10 & 0.05 & -0.05 & 0.03 \\
\hline D 3S & -0.72 & 0.06 & -0.37 & 0.06 & D $3 S$ & -0.48 & 0.07 & -0.24 & 0.07 \\
\hline D $3 \mathrm{~S} \mathrm{rc} 1$ & -0.75 & 0.07 & -0.37 & 0.07 & D $3 \mathrm{~S} \mathrm{rr}$ & -0.50 & 0.06 & -0.26 & 0.06 \\
\hline D $3 S \mathrm{rc} 1 \mathrm{rr}$ & -0.72 & 0.07 & -0.38 & 0.05 & D $3 \mathrm{~S} \mathrm{rc} 1$ & -0.48 & 0.06 & -0.23 & 0.06 \\
\hline D 3S rc2 & -0.75 & 0.07 & -0.40 & 0.03 & D $3 \mathrm{~S} \mathrm{rc} 2$ & -0.48 & 0.07 & -0.27 & 0.03 \\
\hline Average & -0.73 & 0.03 & -0.39 & 0.02 & Average & -0.48 & 0.03 & -0.25 & 0.02 \\
\hline
\end{tabular}

$\mathrm{rr}=$ repeat instrumental analysis on the same $\mathrm{Mg}$-cut solutions;

$\mathrm{rc}=$ repeat column chemistry from another aliquot of dissolved sample solutions;

rd = full chemical replicates, including sample dissolution, column chemistry and instrumental analysis.

The weighted averages are calculated based on inverse-variance weighted model using Isoplot 3.75-4.15. 
Table 3

Temperature $\left({ }^{\circ} \mathrm{C}\right)$ and pressure (GPa) estimates for Hannuoba garnet-bearing xenoliths

\begin{tabular}{|c|c|c|c|c|c|c|c|c|c|c|c|c|}
\hline \multirow[t]{2}{*}{ Sample } & \multirow{2}{*}{$\begin{array}{c}T(W) \\
\text { Cpx-Opx }\end{array}$} & \multirow{2}{*}{$\begin{array}{l}\mathrm{T}(\mathrm{B} \& \mathrm{~K} 1) \\
\mathrm{Ca} \text { in Opx }\end{array}$} & \multirow{2}{*}{$\begin{array}{c}\text { T (B\&K2) } \\
\text { Opx-Grt-Cpx }\end{array}$} & \multirow{2}{*}{$\begin{array}{c}\mathrm{T}(\mathrm{L} \& \mathrm{D}) \\
\mathrm{CaO} \text { in Opx }\end{array}$} & \multirow{2}{*}{$\begin{array}{c}\mathrm{T}(\mathrm{N} \& \mathrm{~T}) \\
\mathrm{Cpx}\end{array}$} & \multicolumn{3}{|c|}{$\mathrm{Mg}$ isotope thermometry } & \multirow{2}{*}{$\begin{array}{l}\mathrm{P}(\mathrm{N} \& \mathrm{G}) \\
\mathrm{Opx}-\mathrm{Grt}\end{array}$} & \multirow{2}{*}{$\begin{array}{l}\mathrm{P}(\mathrm{B} \& \mathrm{~K} 1) \\
\mathrm{Ca} \text { in Opx }\end{array}$} & \multirow{2}{*}{$\begin{array}{c}\text { P (B\&K2) } \\
\text { Opx-Grt-Cpx }\end{array}$} & \multirow{2}{*}{$\begin{array}{l}\text { P (H\&G) } \\
\text { Grt-Opx }\end{array}$} \\
\hline & & & & & & Ol-Grt & Cpx-Grt & Opx-Grt & & & & \\
\hline D $02 \mathrm{~L}$ & 1028 & 1057 & 1052 & 1071 & 1019 & 1622 & 1795 & 1625 & 1.87 & 2.06 & 1.79 & 1.66 \\
\hline D 6S L & 1020 & 1057 & 1019 & 1069 & 1023 & 1376 & 1597 & 1472 & 1.87 & 2.02 & 1.43 & 1.63 \\
\hline D $01 \mathrm{~W}$ & 974 & 997 & 1022 & 1028 & 944 & 776 & 1113 & 1170 & 1.60 & 1.86 & 1.73 & 1.45 \\
\hline D $04 \mathrm{~W}$ & 1032 & 1061 & 1036 & 1077 & 1020 & 1404 & 1421 & 1381 & 1.86 & 1.99 & 1.69 & 1.64 \\
\hline D $06 \mathrm{~W}$ & 973 & 1010 & 1033 & 1039 & 946 & 1264 & 1375 & 1396 & 1.56 & 1.84 & 1.64 & 1.40 \\
\hline D $07 \mathrm{~W}$ & 991 & 990 & 1039 & 1033 & 946 & 1436 & 1397 & 1334 & 1.57 & 1.63 & 1.69 & 1.39 \\
\hline D $09 \mathrm{~W}$ & 975 & 985 & 1011 & 1027 & 943 & 804 & 1006 & 879 & 1.55 & 1.61 & 1.64 & 1.42 \\
\hline D $12 \mathrm{~W}$ & 1021 & 1063 & 1028 & 1072 & 1010 & & & & 1.90 & 2.14 & 1.78 & 1.68 \\
\hline D $22 \mathrm{~W}$ & 991 & 1060 & 1002 & 1066 & 978 & & & & 1.77 & 2.19 & 1.54 & 1.53 \\
\hline $\mathrm{D} 4 \mathrm{~S} \mathrm{~W}$ & 989 & 1028 & 1011 & 1056 & 969 & 1631 & 1904 & 1896 & 1.66 & 1.77 & 1.27 & 1.43 \\
\hline D 5S W & 985 & 997 & 1065 & 1030 & 948 & 1551 & 1599 & 1601 & 1.60 & 1.75 & 1.91 & 1.48 \\
\hline D 7S W & 951 & 959 & 1007 & 1016 & 882 & 2000 & 2817 & 2003 & 1.42 & 1.38 & 1.35 & 1.24 \\
\hline J $13 \mathrm{~W}$ & 997 & 1024 & 1080 & 1046 & 978 & 1202 & 1355 & 1365 & 1.66 & 1.96 & 1.87 & 1.50 \\
\hline J 15 W & 970 & 997 & 1033 & 1032 & 915 & 1184 & & & 1.54 & 1.73 & 1.62 & 1.40 \\
\hline D802 W & 997 & 1030 & 1030 & 1049 & 974 & & & & 1.74 & 1.93 & 1.71 & 1.55 \\
\hline J $805 \mathrm{~W}$ & 975 & 996 & 1044 & 1037 & 934 & & & & 1.48 & 1.62 & 1.55 & 1.32 \\
\hline J $613 \mathrm{~W}$ & 1040 & 1059 & 1084 & 1083 & 1021 & & & & 1.74 & 1.80 & 1.70 & 1.51 \\
\hline J 07 C & & & & & 1029 & 1294 & 1297 & 1357 & & & & \\
\hline D 2 S C & & & & & 895 & 1199 & 1300 & & & & & \\
\hline D 3S C & & & & & 877 & 1039 & 1130 & & & & & \\
\hline
\end{tabular}

Italics indicate values used for Fig. 10.

$\mathrm{T}(\mathrm{W})$ : Cpx-Opx thermometer of Wells (1977).

T (B\&K1) and P (B\&K1): Ca in Opx thermobarometer of Brey and Köhler (1990).

T (B\&K2) and P (B\&K2): Cpx-Opx thermobarometer of Brey and Köhler (1990).

T (L\&D): Wo in Opx thermometer of Lindsley and Dixon (1976).

T (N\&T): Single Cpx thermobarometer of Nimis and Taylor (2000).

P (N\&G): Grt-Opx geobarometer of Nickel and Green (1985), using the temperature calculated by thermometer of Wells (1977).

P (H\&G): Grt-Opx geobarometer of Harley and Green (1985), using the temperature calculated by thermometer of Wells (1977).

$\mathrm{Mg}$ isotope thermometry using parameters provided in Huang et al. (2013). 
Table 4

Magnesium isotopic compositions (\%o) relative to standard DSM3 of mineral separates and whole rock powders from Hannuoba mantle xenoliths

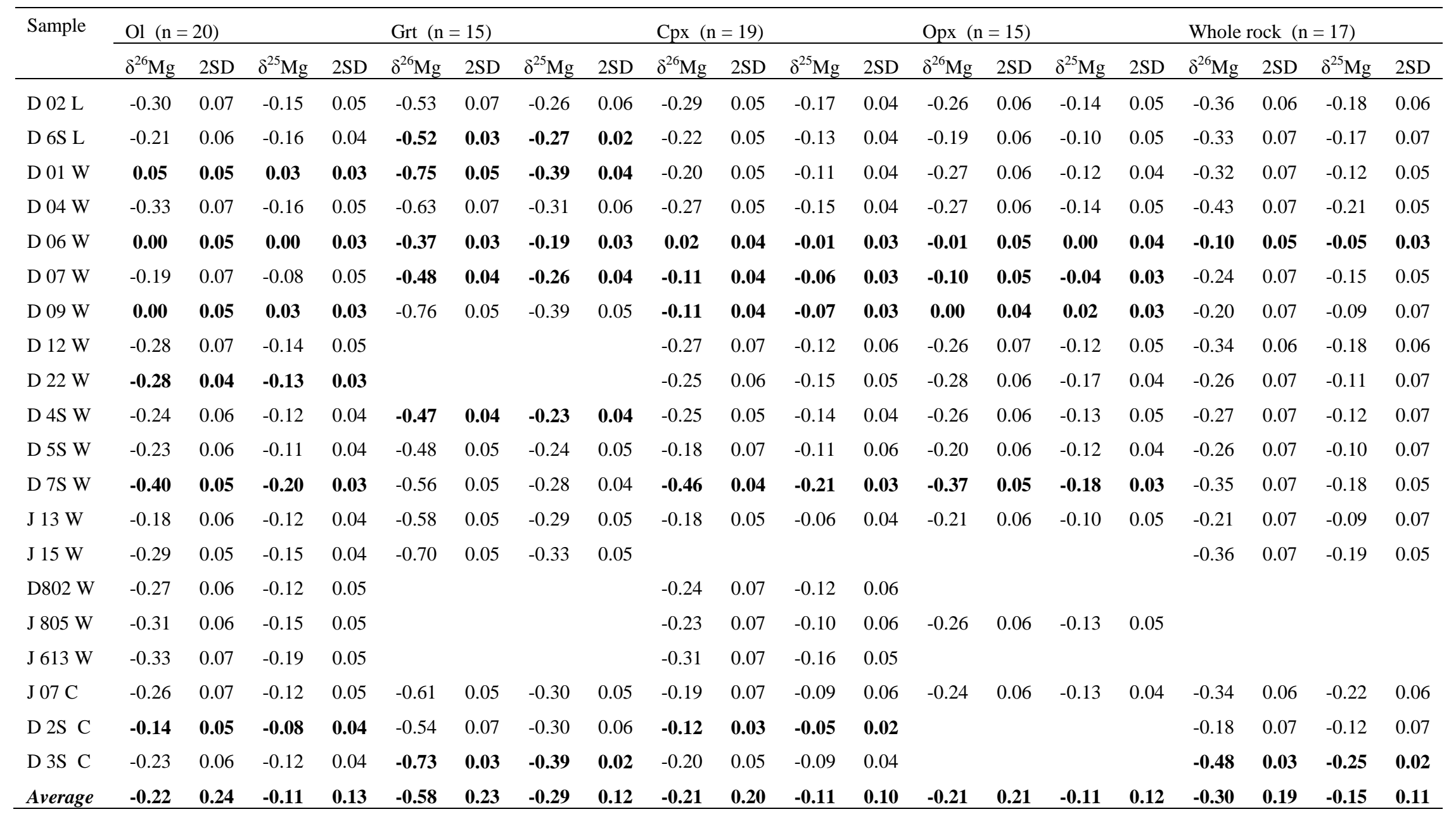

$\mathrm{L}=$ Lherzolite; $\mathrm{W}=$ Websterite; $\mathrm{C}=$ Clinopyroxenite; $\mathrm{n}$ indicates sample numbers for each mineral phase.

$2 \mathrm{SD}=2$ times the standard deviation of the population of $\mathrm{n}$ repeated measurements of the standards during an analytical session.

For samples that have been analyzed more than once, the weighted averages (in bold) are reported. Detailed measurement data are reported in Table 2.

Average values in the last line are arithmetic mean values. 
Table 5

Inter-mineral $\mathrm{Mg}$ isotope fractionations in Hannuoba garnet-bearing xenoliths

\begin{tabular}{|c|c|c|c|c|c|c|c|c|c|c|c|c|c|}
\hline Sample & $\begin{array}{l}\text { Temp. } \\
\left({ }^{\circ} \mathrm{C}\right) \\
\end{array}$ & $\begin{array}{c}\Delta^{26} \mathrm{Mg}_{\mathrm{Ol}-\mathrm{Grt}} \\
(\mathrm{n}=15)\end{array}$ & $2 \mathrm{SD}$ & $\begin{array}{c}\Delta^{26} \mathrm{Mg}_{\mathrm{Cpx}-\mathrm{Grt}} \\
(\mathrm{n}=14)\end{array}$ & $2 \mathrm{SD}$ & $\begin{array}{c}\Delta^{26} \mathrm{Mg}_{\text {Opx-Grt }} \\
\quad(\mathrm{n}=12)\end{array}$ & $2 \mathrm{SD}$ & $\begin{array}{c}\Delta^{26} \mathrm{Mg}_{\text {Cpx-Ol }} \\
(\mathrm{n}=19)\end{array}$ & $2 \mathrm{SD}$ & $\begin{array}{c}\Delta^{26} \mathrm{Mg}_{\text {Opx-Ol }} \\
(\mathrm{n}=15)\end{array}$ & $2 \mathrm{SD}$ & $\begin{array}{c}\Delta^{26} \mathrm{Mg}_{\mathrm{Cpx}-\mathrm{Opx}} \\
\quad(\mathrm{n}=15)\end{array}$ & $2 \mathrm{SD}$ \\
\hline D $02 \mathrm{~L}$ & 1028 & 0.24 & 0.10 & 0.24 & 0.09 & 0.28 & 0.10 & 0.01 & 0.08 & 0.04 & 0.09 & -0.03 & 0.08 \\
\hline D $6 \mathrm{~S} \mathrm{~L}$ & 1020 & 0.31 & 0.07 & 0.30 & 0.06 & 0.33 & 0.07 & -0.02 & 0.08 & 0.01 & 0.09 & -0.03 & 0.08 \\
\hline D $01 \mathrm{~W}$ & 974 & 0.80 & 0.07 & 0.55 & 0.07 & 0.48 & 0.08 & -0.25 & 0.07 & -0.32 & 0.08 & 0.07 & 0.08 \\
\hline D $04 \mathrm{~W}$ & 1032 & 0.30 & 0.10 & 0.36 & 0.09 & 0.37 & 0.10 & 0.06 & 0.08 & 0.06 & 0.09 & 0.00 & 0.08 \\
\hline D $06 \mathrm{~W}$ & 973 & 0.36 & 0.06 & 0.38 & 0.05 & 0.36 & 0.06 & 0.02 & 0.07 & 0.00 & 0.07 & 0.03 & 0.06 \\
\hline D $07 \mathrm{~W}$ & 991 & 0.29 & 0.08 & 0.38 & 0.06 & 0.39 & 0.06 & 0.08 & 0.08 & 0.09 & 0.08 & -0.01 & 0.06 \\
\hline D $09 \mathrm{~W}$ & 975 & 0.76 & 0.07 & 0.65 & 0.07 & 0.76 & 0.07 & -0.11 & 0.06 & 0.00 & 0.07 & -0.11 & 0.06 \\
\hline D $12 \mathrm{~W}$ & 1021 & & & & & & & 0.01 & 0.10 & 0.02 & 0.10 & -0.01 & 0.10 \\
\hline D $22 \mathrm{~W}$ & 991 & & & & & & & 0.03 & 0.07 & -0.01 & 0.07 & 0.04 & 0.08 \\
\hline D 4S W & 989 & 0.24 & 0.08 & 0.22 & 0.06 & 0.21 & 0.07 & -0.02 & 0.08 & -0.02 & 0.09 & 0.01 & 0.08 \\
\hline D $5 \mathrm{~S} \mathrm{~W}$ & 985 & 0.26 & 0.08 & 0.30 & 0.09 & 0.28 & 0.08 & 0.04 & 0.09 & 0.03 & 0.09 & 0.01 & 0.09 \\
\hline D 7S W & 951 & 0.16 & 0.07 & 0.11 & 0.06 & 0.19 & 0.06 & -0.06 & 0.06 & 0.03 & 0.07 & -0.08 & 0.06 \\
\hline J $13 \mathrm{~W}$ & 997 & 0.40 & 0.08 & 0.39 & 0.07 & 0.37 & 0.08 & 0.00 & 0.08 & -0.02 & 0.09 & 0.02 & 0.08 \\
\hline $\mathrm{J} 15 \mathrm{~W}$ & 970 & 0.41 & 0.07 & & & & & & & & & & \\
\hline D802 W & 997 & & & & & & & 0.03 & 0.09 & & & & \\
\hline J $805 \mathrm{~W}$ & 975 & & & & & & & 0.07 & 0.09 & 0.04 & 0.09 & 0.03 & 0.09 \\
\hline J $613 \mathrm{~W}$ & 1040 & & & & & & & 0.02 & 0.10 & & & & \\
\hline J $07 \mathrm{C}$ & 1029 & 0.35 & 0.09 & 0.42 & 0.09 & 0.38 & 0.08 & 0.08 & 0.10 & 0.03 & 0.09 & 0.05 & 0.09 \\
\hline D $2 \mathrm{~S} \mathrm{C}$ & 895 & 0.40 & 0.09 & 0.42 & 0.08 & & & 0.03 & 0.06 & & & & \\
\hline D $3 \mathrm{~S} \mathrm{C}$ & 877 & 0.50 & 0.07 & 0.53 & 0.06 & & & 0.03 & 0.08 & & & & \\
\hline Average & & 0.39 & 0.36 & 0.38 & 0.28 & 0.37 & 0.29 & 0.00 & 0.15 & 0.00 & 0.19 & $\mathbf{0 . 0 0}$ & 0.10 \\
\hline
\end{tabular}

Temp. $=$ Temperature 
Table 6

Magnesium isotopic compositions (\%) of mineral separates and whole rock powders from Hannuoba garnet-free pyroxenite xenoliths, basalts, and a Qinling garnet peridotite xenolith

\begin{tabular}{|c|c|c|c|c|c|c|c|c|c|c|c|c|c|c|c|c|}
\hline \multirow[t]{2}{*}{ Sample } & \multirow[t]{2}{*}{ Rock type } & \multicolumn{4}{|l|}{ Cpx } & \multicolumn{4}{|l|}{ Opx } & \multicolumn{4}{|c|}{ Whole rock } & \multirow[t]{2}{*}{$\mathrm{T}$} & \multirow[t]{2}{*}{$\Delta^{26} \mathrm{Mg}_{\mathrm{Cpx}-\mathrm{Opx}}$} & \multirow[t]{2}{*}{$2 \mathrm{SD}$} \\
\hline & & $\delta^{26} \mathrm{Mg}$ & $2 \mathrm{SD}$ & $\delta^{25} \mathrm{Mg}$ & $2 \mathrm{SD}$ & $\delta^{26} \mathrm{Mg}$ & $2 \mathrm{SD}$ & $\delta^{25} \mathrm{Mg}$ & $2 \mathrm{SD}$ & $\delta^{26} \mathrm{Mg}$ & $2 \mathrm{SD}$ & $\delta^{25} \mathrm{Mg}$ & $2 \mathrm{SD}$ & & & \\
\hline D 11 & Cr Webst & -0.33 & 0.06 & -0.11 & 0.05 & -0.28 & 0.06 & -0.16 & 0.05 & -0.32 & 0.06 & -0.156 & 0.06 & 1039 & -0.04 & 0.09 \\
\hline D 17 & Cr Webst & -0.25 & 0.06 & -0.11 & 0.05 & -0.23 & 0.06 & -0.13 & 0.04 & & & & & 844 & -0.02 & 0.08 \\
\hline D 18 & Cr Webst & -0.24 & 0.07 & -0.13 & 0.06 & -0.28 & 0.06 & -0.15 & 0.05 & & & & & 849 & 0.04 & 0.09 \\
\hline D 19 & Al Webst & -0.29 & 0.07 & -0.12 & 0.06 & -0.21 & 0.06 & -0.11 & 0.04 & -0.26 & 0.06 & -0.13 & 0.06 & 868 & -0.08 & 0.09 \\
\hline D 23 & Cpxnt & -1.34 & 0.06 & -0.69 & 0.05 & & & & & -1.26 & 0.06 & -0.67 & 0.06 & & & \\
\hline J 53 & Cpxnt & -1.47 & 0.07 & -0.76 & 0.06 & & & & & -1.51 & 0.07 & -0.80 & 0.05 & & & \\
\hline $\mathrm{J}$ 53rr & Cpxnt & -1.38 & 0.07 & -0.68 & 0.05 & & & & & -1.40 & 0.06 & -0.77 & 0.06 & & & \\
\hline $\mathrm{J} 53 \mathrm{rr} 2$ & Cpxnt & -1.39 & 0.07 & -0.73 & 0.05 & & & & & & & & & & & \\
\hline J 52 & Opxnt & & & & & -0.21 & 0.07 & -0.12 & 0.05 & -0.17 & 0.06 & -0.09 & 0.06 & 873 & & \\
\hline DA 0605 & Alkali Basalt & & & & & & & & & -0.50 & 0.08 & -0.28 & 0.07 & & & \\
\hline DA 0605rr & Alkali Basalt & & & & & & & & & -0.51 & 0.07 & -0.26 & 0.05 & & & \\
\hline DA 0608 & Tholeiitic Basalt & & & & & & & & & -0.35 & 0.06 & -0.18 & 0.05 & & & \\
\hline QL 08-1 & Grt Peridotite & & & & & & & & & -0.39 & 0.08 & -0.21 & 0.07 & & & \\
\hline
\end{tabular}

Webst $=$ websterite Cpxnt $=$ Clinopyroxenite $;$ Opxnt $=$ Orthopyroxenite $;$ Grt $=$ garnet . 


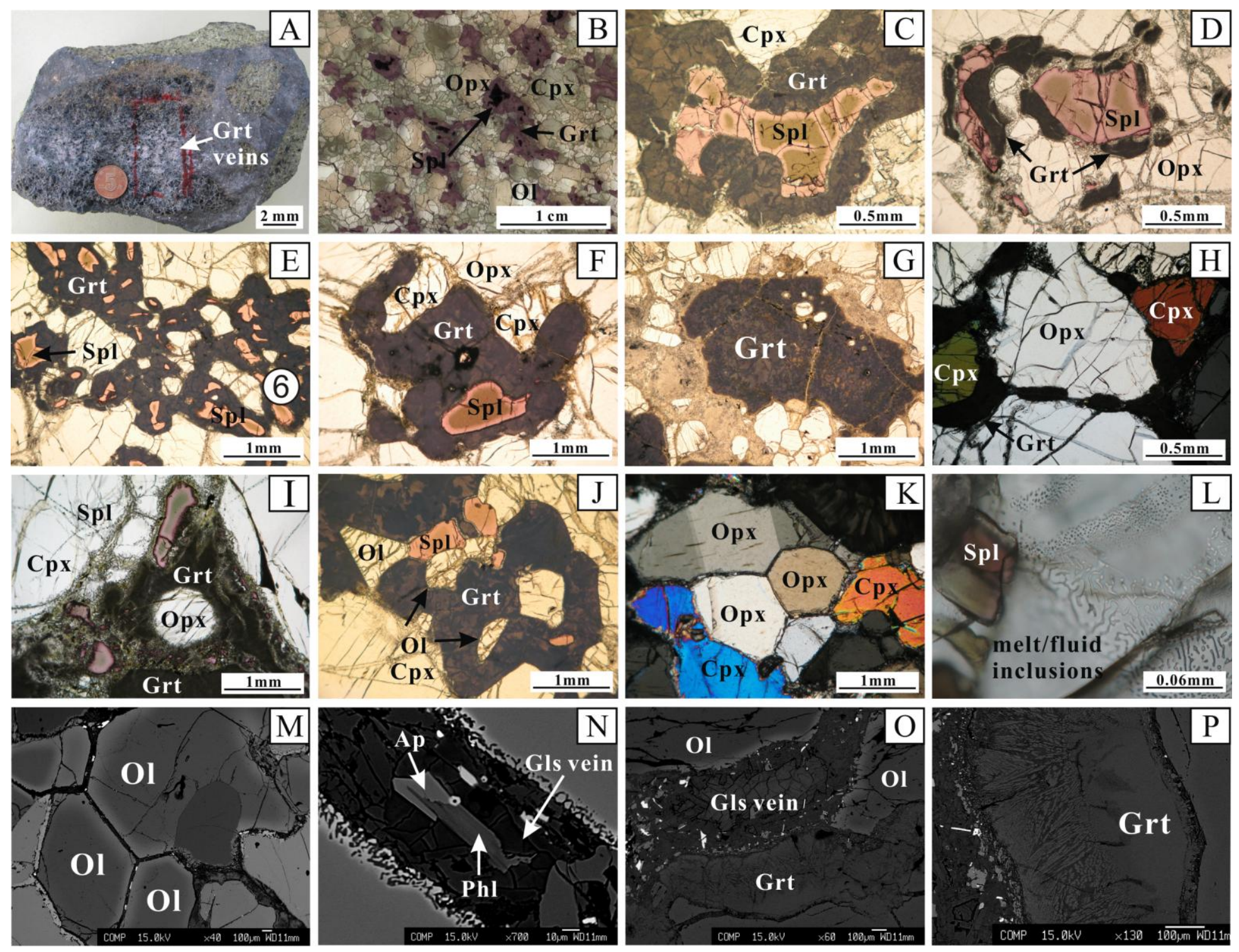

Fig. 1 

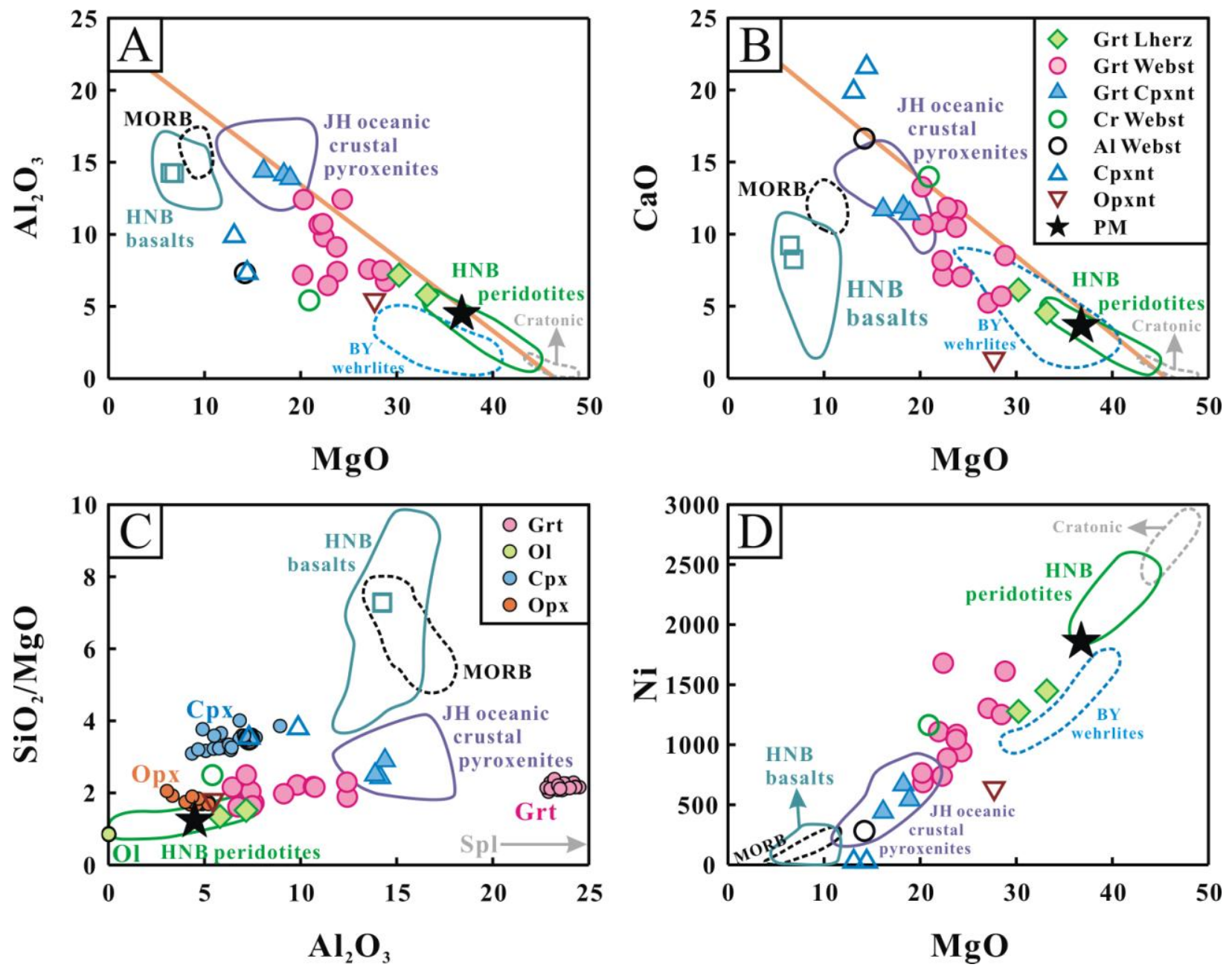

Fig. 2 

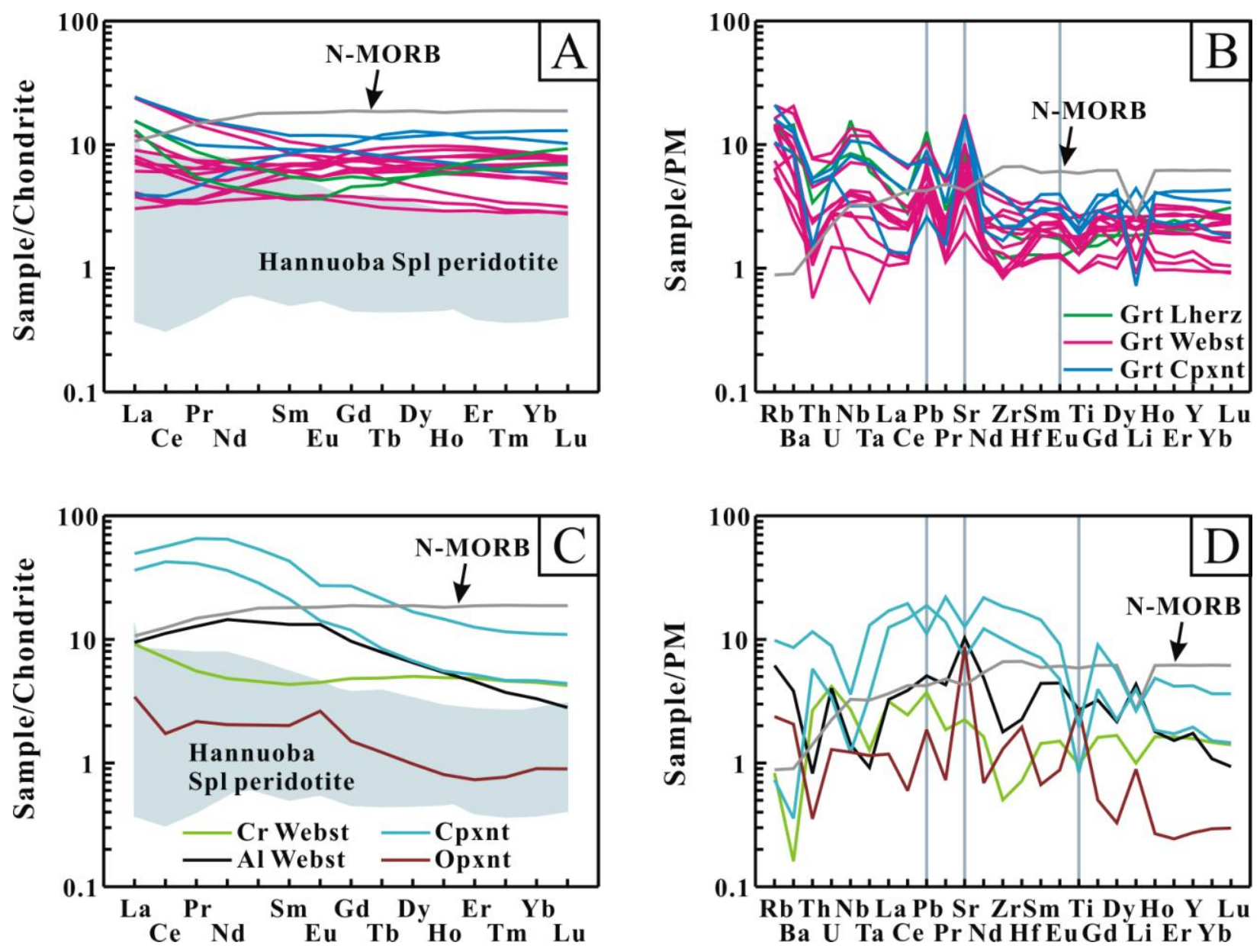

Fig. 3 

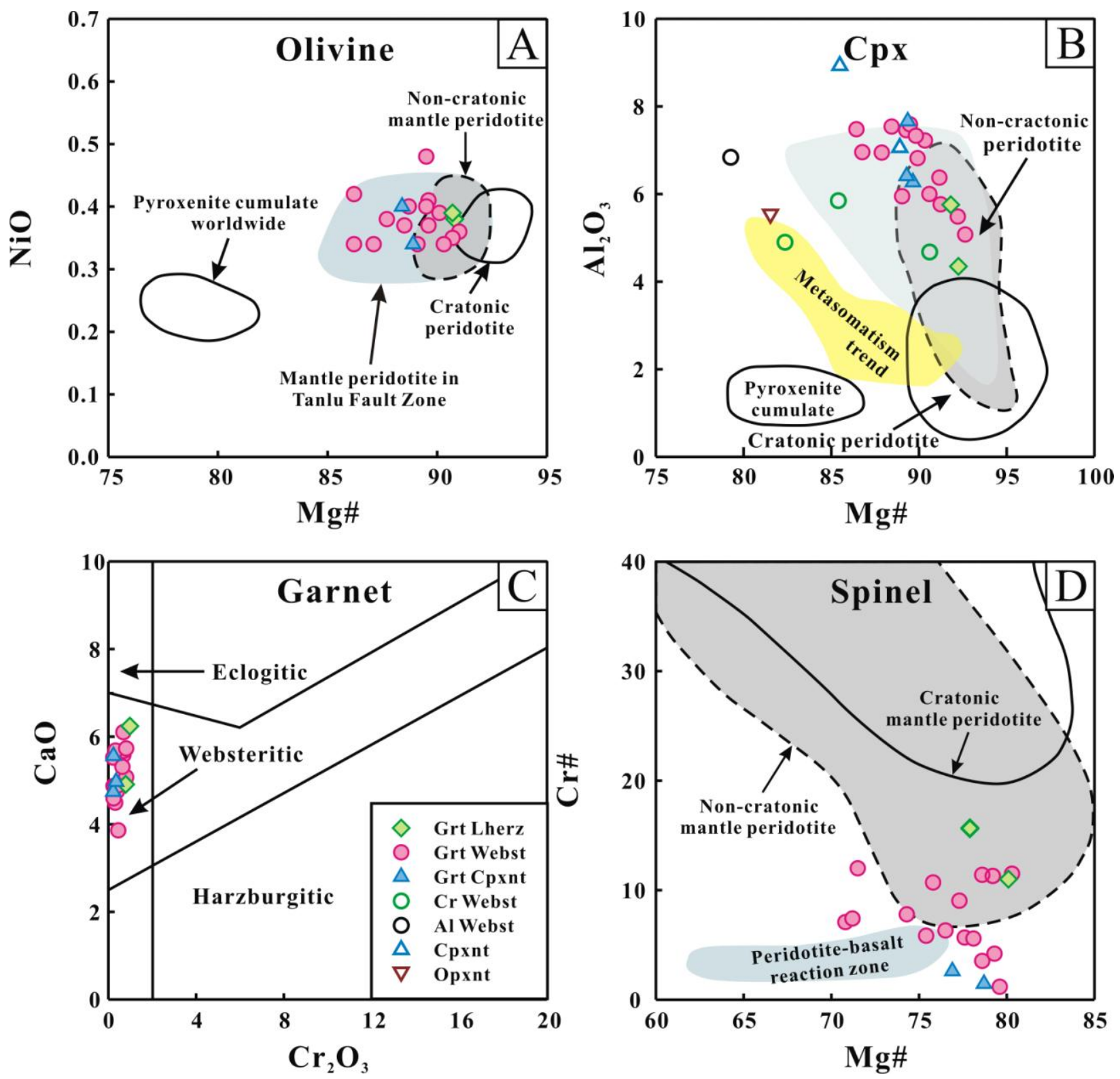

Fig. 4 


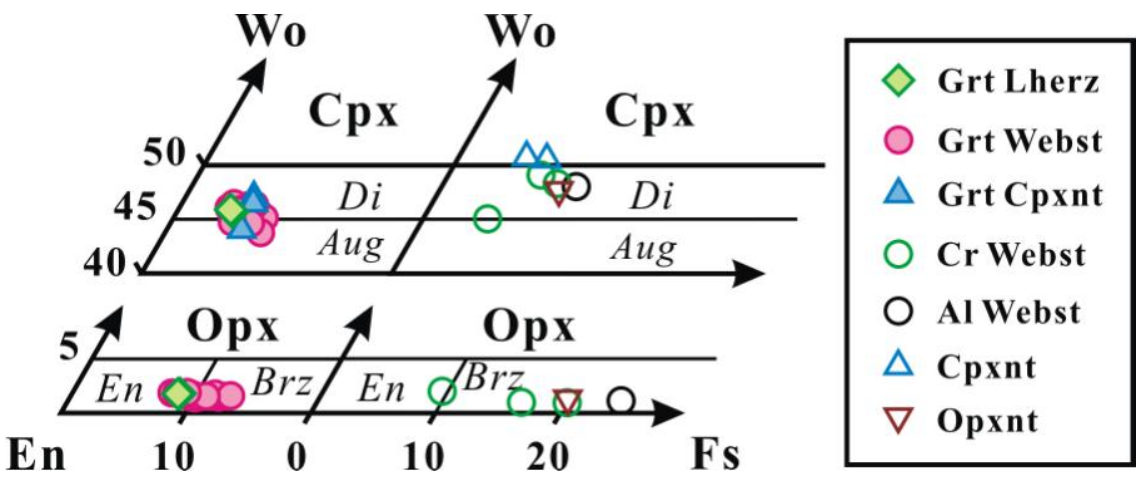

Fig. 5 

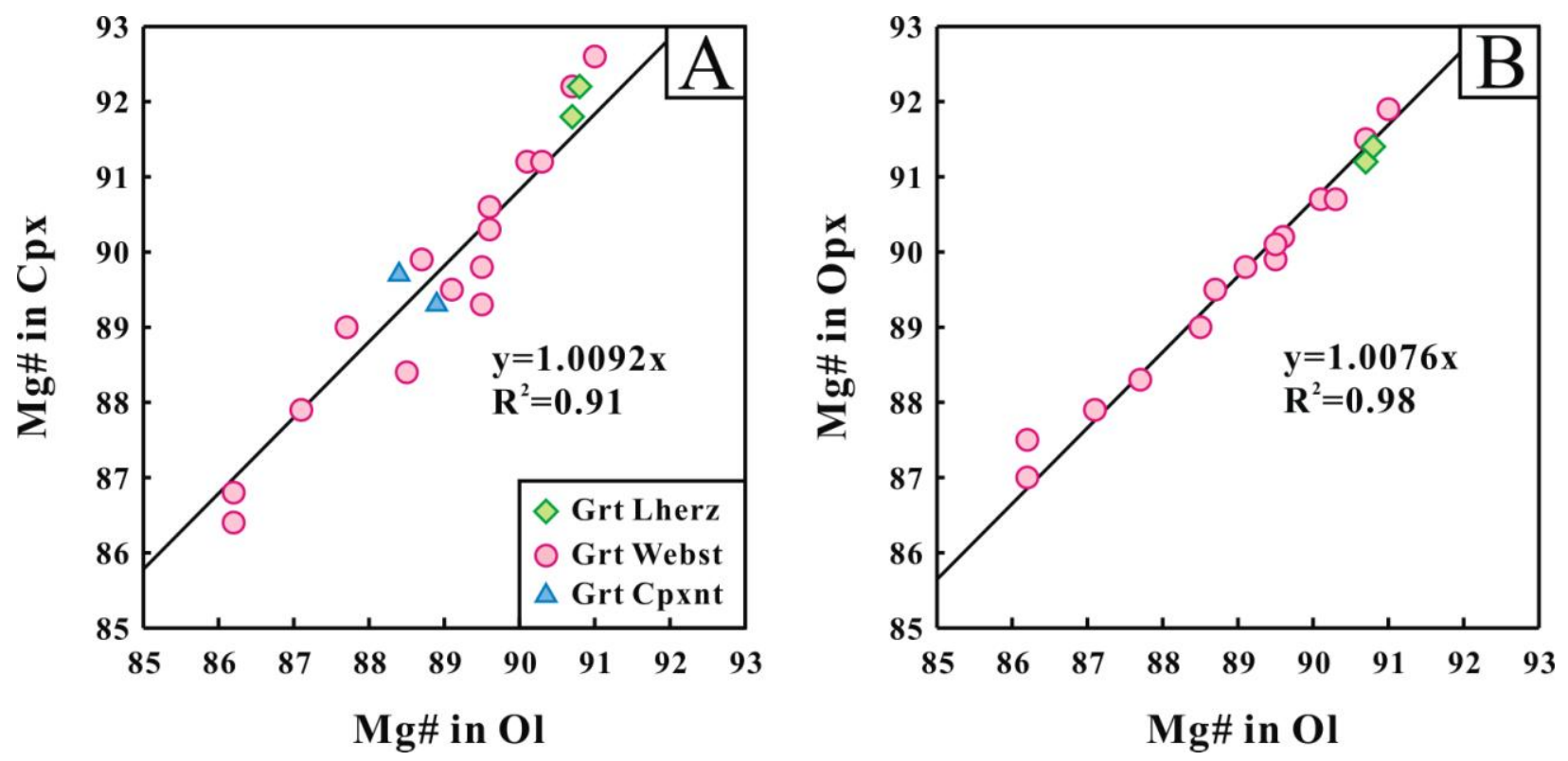

Fig. 6 

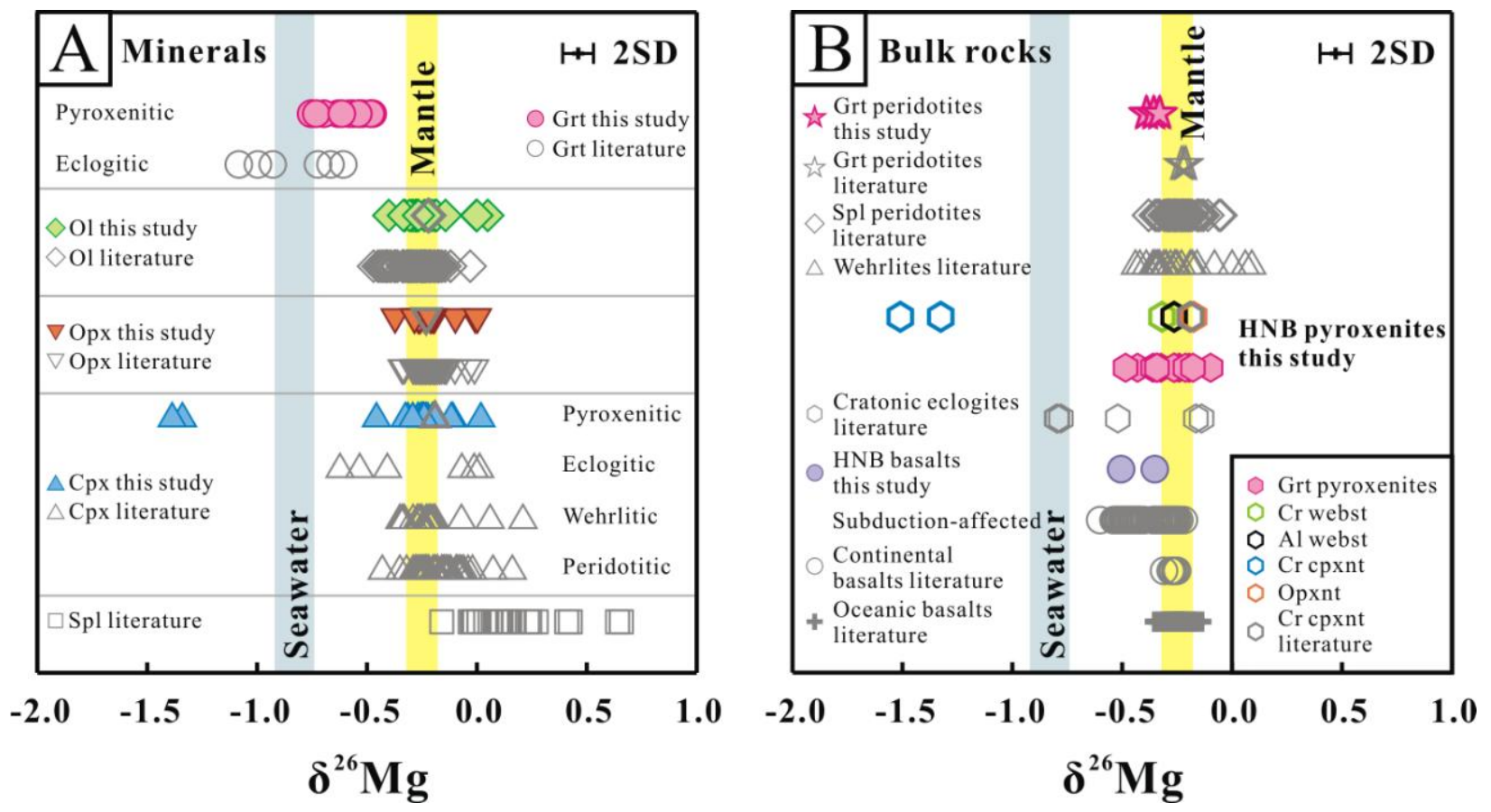

Fig. 7 


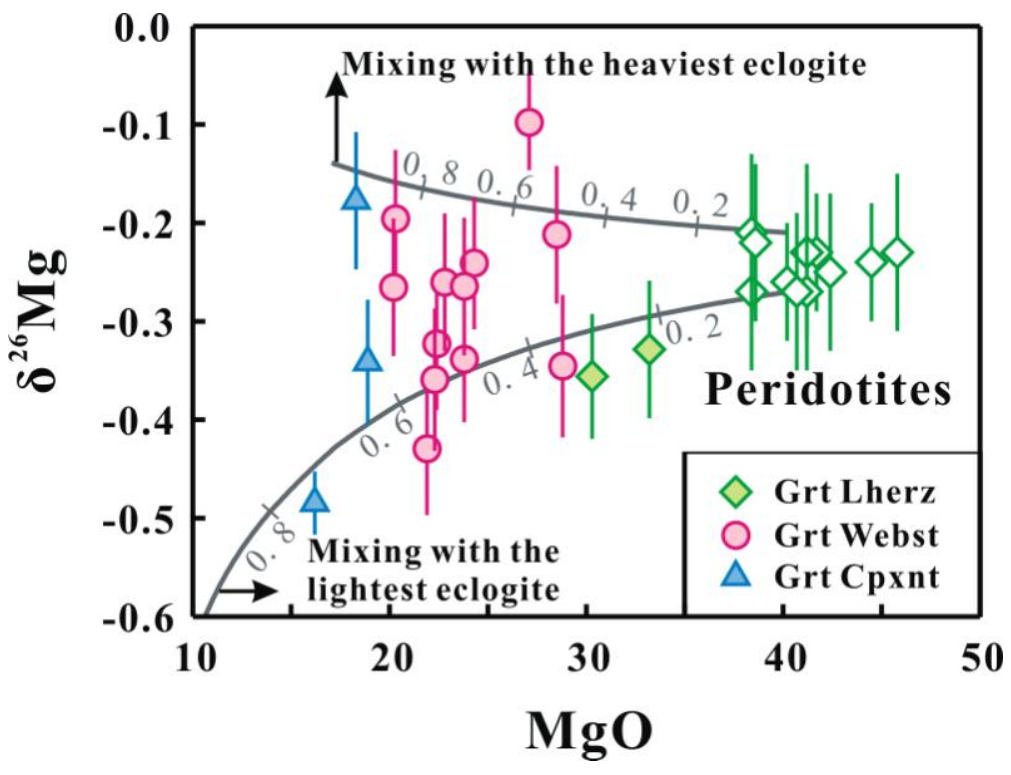

Fig. 8 


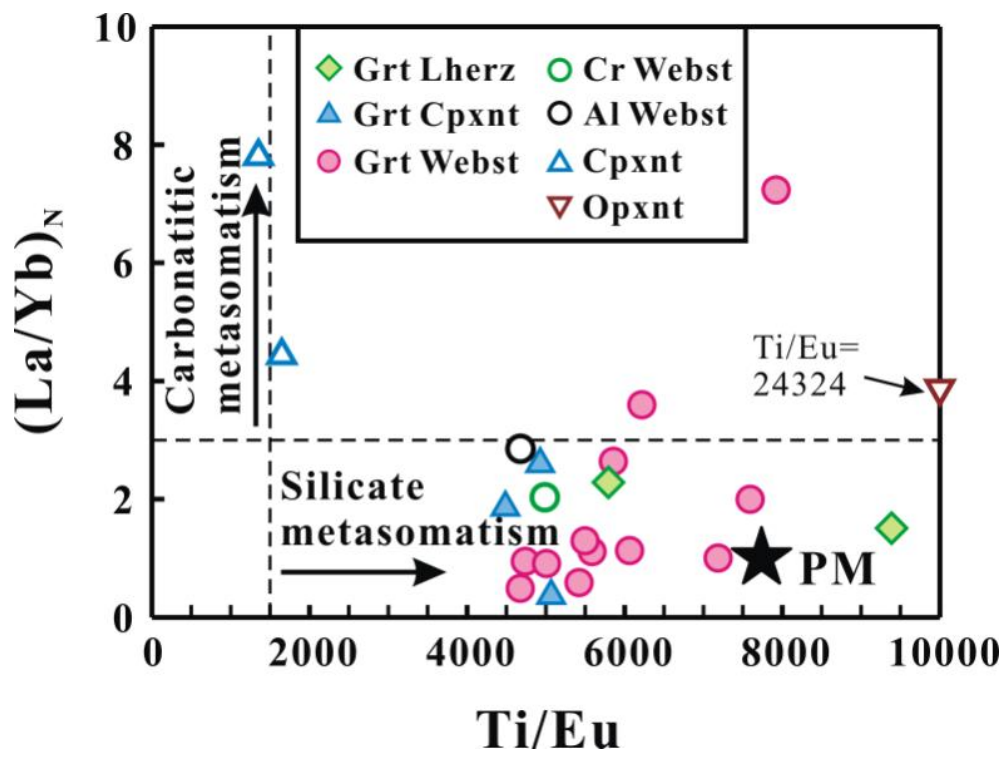

Fig. 9 

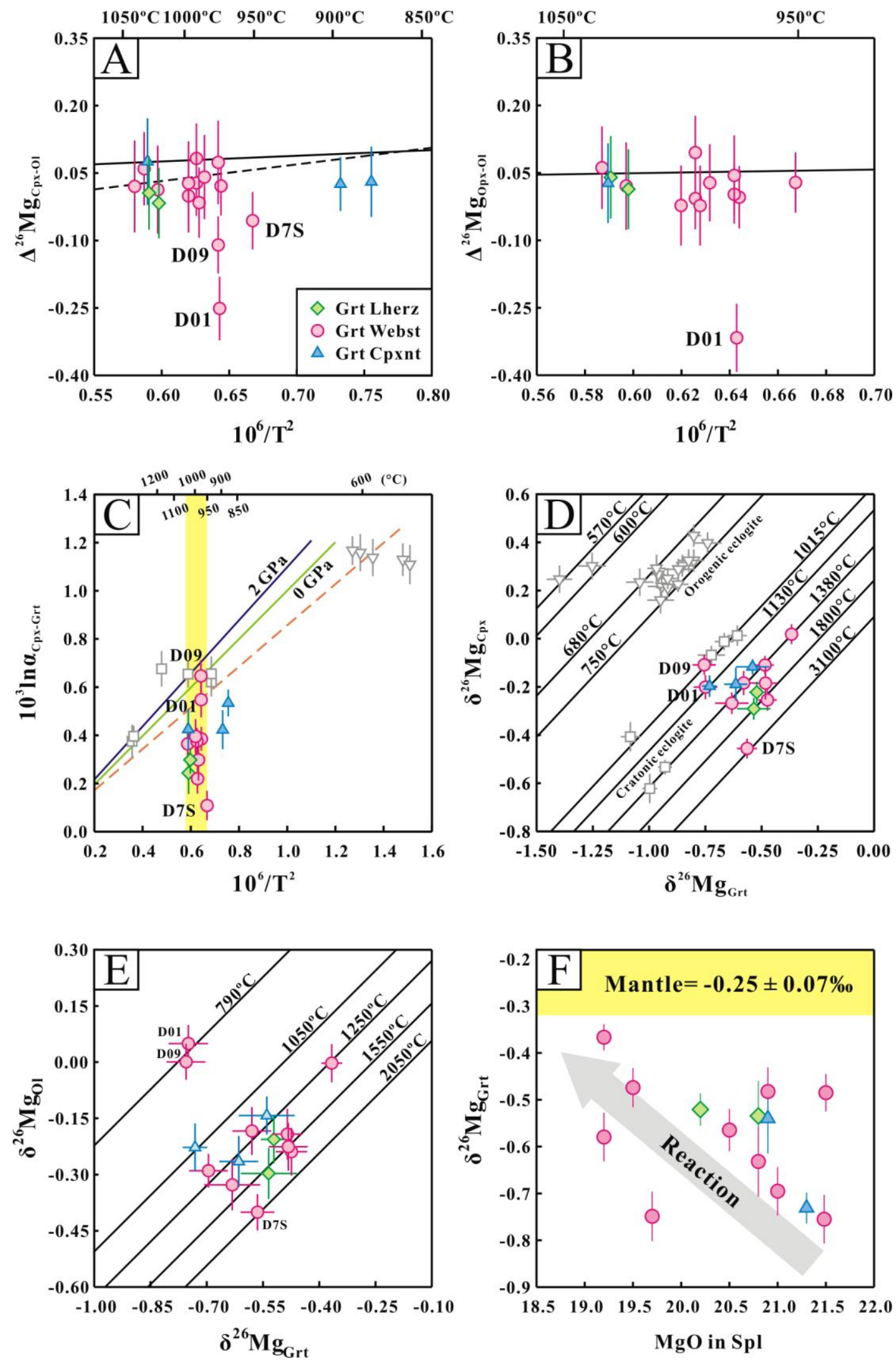

Fig. 10 

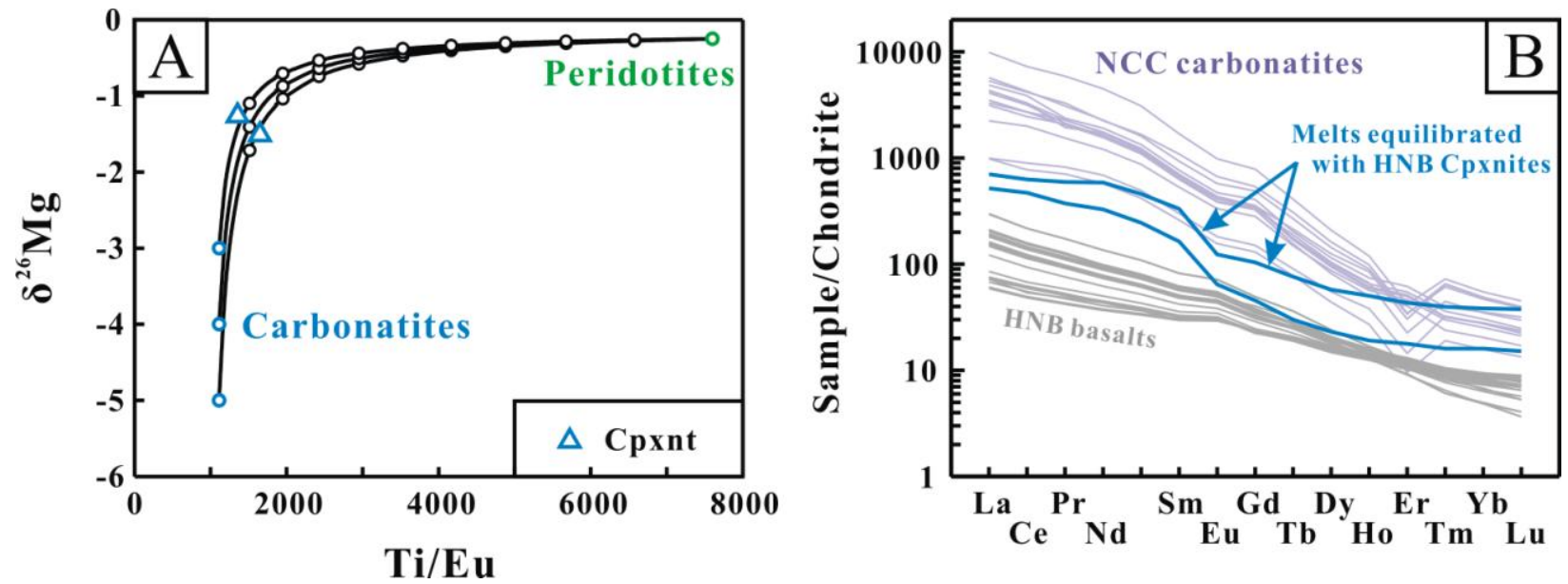

Fig. 11 